\title{
Recovery from Hypersaline-Stress-Induced Immunity Damage and Intestinal-Microbiota Changes through Dietary $\beta$-glucan Supplementation in Nile tilapia (Oreochromis niloticus)
}

\author{
Chang $\mathrm{Xu}^{1,2,+}$, Yantong Suo ${ }^{2,+}$, Xiaodan Wang $^{2}{ }^{1}$, Jian G Qin ${ }^{3}$, Liqiao Chen ${ }^{2} \mathbb{D}$ and \\ Erchao Li 1,2,*(D) \\ 1 Key Laboratory of Tropical Hydrobiology and Biotechnology of Hainan Province, \\ Hainan Aquaculture Breeding Engineering Research Center, College of Marine Sciences, \\ Hainan University, Haikou 570228, China; cxu@hainanu.edu.cn \\ 2 School of Life Sciences, East China Normal University, Shanghai 200241, China; suoyantong@163.com (Y.S.); \\ xdwang@bio.ecnu.edu.cn (X.W.); lqchen@bio.ecnu.edu.cn (L.C.) \\ 3 School of Biological Sciences, Flinders University, Adelaide, SA 5001, Australia; jian.qin@flinders.edu.au \\ * Correspondence: ecli@bio.ecnu.edu.cn \\ + These authors contributed equally to this work.
}

Received: 4 November 2020; Accepted: 27 November 2020; Published: 30 November 2020

Simple Summary: Long-term hypersaline stress can induce coagulation disorders and splenomegaly and down-regulate the complement pathway in tilapia, which can increase risk in healthy breeding. As a prebiotic, $\beta$-glucan dietary supplementation can significantly reduce enlarged spleen resulting from hypersaline stress. The hematological aspects of the red blood cell count, hematocrit, red cell distribution width, platelet count, and plateletcrit were also decreased by supplementation with dietary $\beta$-glucan. In the spleen and intestine, $\beta$-glucan intake significantly decreased the high expression of immune-related genes due to hypersaline stress resulting from $\beta$-glucan intake in tilapia. $\beta$-glucan supplementation also significantly increased the abundance of beneficial microbiota such as Lactobacillus, Phycicoccus, and Rikenellaceae in the intestine. In summary, $\beta$-glucan intake can relieve tissue damage and optimize the intestinal microbiota of tilapia in brackish water and improve fish health.

\begin{abstract}
Long-term exposure to hyperosmotic environments can induce severe immune damage and increase risk in tilapia breeding. As an effective immunoregulator, $\beta$-glucan has attracted extensive attention in nutritional research and given rise to high expectations of improving health status and alleviating organismal damage in tilapia, Oreochromis niloticus, in brackish water. In this study, an 8-week cultivation experiment was conducted on tilapia fed a basal diet or diets with $\beta$-glucan supplementation in freshwater (control) and brackish water. Growth performance, hematological aspects, immune cytokine expression, and the intestinal microbiota of tilapia were analyzed. The results indicated that supplementation with $\beta$-glucan significantly reduced the enlarged spleen of tilapia resulting from hypersaline stress. Tilapia fed $\beta$-glucan showed significantly-greater decreases in the red blood cell count, hematocrit, red cell distribution width, platelet count, and plateletcrit than those fed the basal diet. $\beta$-glucan significantly decreased the high expression of immune-related genes in the spleen induced by hyperosmotic stress. In the intestine, the high migration inhibitory factor-2 (MIF-2) and IL-1 $\beta$ gene expression induced by hypersaline stress was significantly reduced. $\beta$-glucan supplementation also significantly increased the abundance of beneficial microbiota such as Lactobacillus, Phycicoccus, and Rikenellaceae. Therefore, dietary $\beta$-glucan supplementation can significantly reduce spleen enlargement and improve immune function in tilapia in brackish water. $\beta$-glucan intake can also optimize the intestinal microbiota of tilapia in brackish water and improve fish health.
\end{abstract}


Keywords: Nile tilapia; immune function; hematology; intestinal microbiota

\section{Introduction}

As a biologically-active immunomodulator, $\beta$-glucan is a ubiquitous component of fungi, yeast, oats, and seaweed [1]. $\beta$-glucan can be recognized by the innate immune system, which plays an essential role in host defense [2]. In pharmaceutics, $\beta$-glucan shows potential therapeutic value for immune improvement, along with anti-inflammatory and anti-cancer effects [3,4]. As a dietary additive, the positive effect of $\beta$-glucan is also found in various aquatic animals under stress conditions. Resistance capacity against bacterial infection and immune function can be enhanced by $\beta$-glucan addition in Oreochromis niloticus [5,6]. $\beta$-glucan supplementation also can improve growth and immune function in zebrafish [7], Pagrus major [8], Ictalurus punctatus [9], and Pseudosciaena crocea [10]. In Litopenaeus vannamei, dietary $\beta$-glucan can significantly improve growth performance and induce higher respiratory burst and higher richness of probiotics in the intestine versus basal diets at low salinity $[11,12]$.

In mammals, $\beta$-glucans have a significant impact on the intestinal microbiota, and in turn on organismal health [13]. In addition to its effective immunomodulatory properties, $\beta$-glucan is also a typical fiber digested by intestinal enzymes to produce short-chain fatty acids (SCFAs) [14]. SCFAs are beneficial to reduce the $\mathrm{pH}$ and are thus beneficial for the competitive exclusion of pathogens in the intestine [15]. Intestinal bacterial metabolism in aquatic animals shows important functions in health regulation and nutrient absorption [16]. Dietary $\beta$-glucan supplementation can improve intestinal microbiota communities in Cyprinus carpio [17], Scophthalmus maximus [18], Rutilus Frisii kutum [19], and Cyprinus carpio L [20]. $\beta$-glucans can also increase the dominance of the intestinal microbiota richness in L. vannamei under the conditions of ammonia and low-salinity stress [12,21].

For aquatic animals, salinity is a key ecological index that directly influences growth, physiological status, immune function, and nutritional value [22]. In our previous research, chronic hyperosmotic stress induced an intumescent spleen and enlarged macrophage centers in head kidney and suppressed immune function in O. niloticus [23]. As the two largest lymphoid and immunocompetent organs, the spleen and head kidney are sensitive to environmental changes $[24,25]$. In O. mossambicus, acute salinity stress can increase phagocytosis, respiratory burst activity, and humoral immune reactions in the spleen and head kidney [26]. Chronic salinity stress can also increase susceptibility to streptococcus infection in O. mossambicus [27]. After exposure to endosulfan at a level equivalent to $\frac{1}{2} \mathrm{LC} 50$ for $96 \mathrm{~h}$, a lower spleen cell viability and relative spleen weight were found in O. niloticus [28]. Similarly, exposure to cadmium chloride $(20.93 \mathrm{mg} / \mathrm{L})$ for $120 \mathrm{~h}$ can cause significant changes in melano-macrophage centers (MMCs) and free macrophages in the spleen and head kidney of O. mossambicus [29]. The blood parameters of teleost fish are also sensitive to salinity stress, as evidenced in Huso [30], Rachycentron canadum [31], Notopterus notopterus [32], and Acipenser brevirostrum [33].

Nile tilapia (Oreochromis niloticus) is the most economically-important and extensively-cultured aquatic species worldwide. Although tilapia exhibit strong adaptation to environmental salinity, hypersaline stress can still damage immune function and increase the risks of disease and death. Previous research has indicated that environmental salinity can significantly alter the gut microbiota and induce impaired immune function in O. niloticus [23,34]. Therefore, it is necessary to find an effective method to mitigate or eliminate the negative impacts in tilapia induced by environmental hyperosmotic stress. In this study, the effects of $\beta$-glucan supplementation in the diet on growth performance, hematology, histology, immunity gene expression, and intestinal microbiota communities were analyzed to evaluate the comprehensive health status response in Nile tilapia under hypersaline environments. This study will provide new insights to explore the role of dietary nutrient manipulation in fish to cope with environmental stress. 


\section{Materials and Methods}

\subsection{Ethical Approval}

The animal ethics protocol was approved by the East China Normal University Experimental Animal Ethics Committee (No. f20190201).

\subsection{Experimental Diets}

Isonitrogenous and isoenergetic experimental diets were formulated with three concentrations of $\beta$-glucan $(0,0.2$ and $0.4 \%$ ). Raw materials were crushed with a pulverizer and sieved through a $60-\mu \mathrm{m}$ mesh and then mixed evenly. Each mixture was dissolved by adding deionized water and then wet-extruded into 2.5-mm-diameter pellets using a double-helix plodder (F-26, SCUT industrial factory, Guangdong, China). The scattered pellets were air-dried at room temperature until $<10 \%$ moisture content was attained. Pellets were graded to various sizes by 12- and 8-mesh sieves and stored at $-20{ }^{\circ} \mathrm{C}$ until use. Ingredient and proximate compositions of the three experimental diets are given in Table 1.

Table 1. Ingredient formulation ( $\mathrm{g} / \mathrm{kg}$ dry basis) of three experimental diets fed to Oreochromis niloticus.

\begin{tabular}{cccc}
\hline & \multicolumn{3}{c}{$\beta$-glucan Contents (\%) } \\
\cline { 2 - 4 } Ingredients & $\mathbf{0}$ & $\mathbf{0 . 2 0}$ & $\mathbf{0 . 4 0}$ \\
\hline Fish meal & 80.00 & 80.00 & 80.00 \\
Soybean meal & 450.00 & 450.00 & 450.00 \\
Maize meal & 250.00 & 250.00 & 250.00 \\
Wheat middlings & 74.00 & 74.00 & 74.00 \\
Maize oil & 36.00 & 36.00 & 36.00 \\
Dicalcium & 10.00 & 10.00 & 10.00 \\
Vitamin premix a & 5.00 & 5.00 & 5.00 \\
Mineral premix b & 5.00 & 5.00 & 5.00 \\
Cellulose & 60.00 & 57.73 & 55.46 \\
Carboxymethyl cellulose & 30.00 & 30.00 & 30.00 \\
$\beta_{\text {-glucan c }}^{\text {c }}$ & 0.00 & 2.27 & 4.54 \\
Total & 1000.00 & 1000.00 & 1000.00 \\
\hline
\end{tabular}

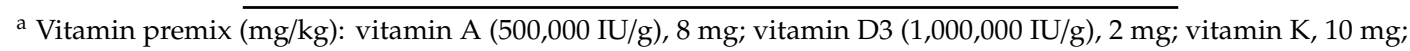
vitamin E, $200 \mathrm{mg}$; thiamine, $10 \mathrm{mg}$; riboflavin, $12 \mathrm{mg}$; pyridoxine, $10 \mathrm{mg}$; calcium pantothenate, $32 \mathrm{mg}$; nicotinic acid, $80 \mathrm{mg}$; folic acid, $2 \mathrm{mg}$; vitamin B12, $0.01 \mathrm{mg}$; biotin, $0.2 \mathrm{mg}$; choline chloride, $400 \mathrm{mg}$; vitamin C-2- polyphosphate (150 mg/g vitamin C activity), $400 \mathrm{mg} .{ }^{\mathrm{b}}$ Mineral premix (mg/kg): zinc (ZnSO4.7H2O), $50.0 \mathrm{mg}$; iron (FeSO4.7H2O), $40 \mathrm{mg}$; manganese (MnSO4.7H2O), $15.3 \mathrm{mg}$; copper (CuCl2), $3.8 \mathrm{mg}$; iodine (KI), $5 \mathrm{mg}$; cobalt (CoCl2.6H2O), $0.05 \mathrm{mg}$; selenium (Na2SeO3), $0.09 \mathrm{mg} .{ }^{c} \beta$-glucan in this study was extracted from yeast cell walls and purchased from Swiss ABAC. Research and Development Co., Ltd (Barden, Swiss).

\subsection{Experimental Fish and Management Procedure}

The juvenile Nile tilapia (all males) were obtained from a local farm in Hainan, China. All fish were acclimated in four tanks for one week with commercial diets. During acclimation, the salinity in the three tanks was gradually increased to 16 practical salinity units (psu) at a daily rate of 4 psu by adding sea salt. After the salinity reached the target value, fish with an initial weight of $1.28 \pm 0.03 \mathrm{~g}$ were randomly assigned to 16 tanks $(750 \mathrm{~L})$ at a density of 35 fish per tank. There were four experimental treatments (freshwater-0\% $\beta$-glucan, 16 psu- $0 \% \beta$-glucan, 16 psu- $0.2 \% \beta$-glucan, and 16 psu- $0.4 \%$ $\beta$-glucan) with four replicates each. During the 53-day experiment, fish were fed to satiation twice daily (0800 and $1400 \mathrm{~h}$ ). Two tanks (freshwater and brackish water) were used for water storage before entering the experimental system. The daily water exchange rate was $50 \%$ of the water volume. Animals were illuminated by natural light with a specific photoperiod. Water quality parameters were checked every three days. The concentration of dissolved oxygen was $6.5-7.5 \mathrm{mg} / \mathrm{L}, \mathrm{pH}$ averaged $7.50 \pm 0.30$, ammonia- $\mathrm{N}$ was $<0.05$, and water temperature averaged $30 \pm 2{ }^{\circ} \mathrm{C}$. 


\subsection{Sample Collection}

At the end of the cultivation, all fish were fasted for $24 \mathrm{~h}$. Subsequently, the fish were anesthetized in 30 ppm MS-222 before being counted and weighed to determine survival and weight gain [35,36]. The blood of each fish was individually sampled by caudal sinus puncture with plastic sterile syringes. Blood samples were transferred to lithium heparin tubes for hematological determination. The spleen, head kidney, and mid-intestine of 15 fish in each tank were dissected quickly and then stored in liquid nitrogen to analyze immune gene mRNA and intestinal microflora. The spleens of five fish in each tank were dissected and weighed to determine relative spleen weight. Survival, weight gain, and relative spleen weight were calculated as follows:

Survival $(\%)=($ final fish number/initial fish number $) \times 100$

Weight gain $(W G, \%)=($ final weight $(\mathrm{g})-$ initial weight $(\mathrm{g})) /$ initial weight $(\mathrm{g}) \times 100$

Relative spleen weight $($ RSW, $\%)=($ wet spleen weight $) /($ wet body weight $) \times 100$

\subsection{Hematological Assay}

The red blood cell count (RBC, 1,012/L), hematocrit (HCT, \%), red cell distribution width (RDW, \%), white blood cell count (WBC, 109/L), platelet count (PLT, 109/L) and plateletcrit (PCT, \%) were investigated by an automated hematological analyzer (BC-2800vet, Shenzhen, Mindray Bio-Medical Electronics, Shenzhen, China).

\subsection{Immune-Related Gene Expression}

Total RNA in the spleen, head kidney, and intestine was extracted with the TRIzol reagent (RN0101, Aidlab, Beijing, China). RNA quality and quantity were analyzed using a NanoDrop 2000 spectrophotometer (Thermo, Wilmington, NC, USA). After the quantity was analyzed, $1 \mu \mathrm{g}$ total RNA was reverse transcribed using the PrimeScripTM RT Master Mix (RR047A, Takara, Japan). The system program was $42^{\circ} \mathrm{C}$ for $2 \mathrm{~min}$ to remove genomic DNA followed by $37^{\circ} \mathrm{C}$ for $15 \mathrm{~min}$ and $85^{\circ} \mathrm{C}$ for $5 \mathrm{~s}$ to complete reverse transcription. Six replicates per treatment were run for each gene with elongation factor- $1 \alpha(E F-1 \alpha)$ as the internal control. Primers of interleukin-1 $\beta(I L-1 \beta)$, migration-inhibitory factor-2 (MIF-2), transforming growth factor- $\beta 1$ (TGF- $\beta 1$ ), and tumor necrosis factor- $\alpha$ (TNF- $\alpha$ ) were designed and validated by Primer Premier 6.0 according to National Coalition Building Institute (NCBI) (Table 2).

Table 2. Primers designed in the qPCR.

\begin{tabular}{|c|c|c|}
\hline Gene & $5^{\prime}-3^{\prime}$ Primer Sequence & GenBank Accession No. \\
\hline$I L-1 \beta$ & $\begin{array}{c}\text { F: GAGCACAGAATTCCAGGATGAAAG } \\
\text { R: TGAACTGAGGTGGTCCAGCTGT }\end{array}$ & XM_019365841.1 \\
\hline MIF-2 & $\begin{array}{l}\text { F: AGCAGAAGCAGGAAGGCGAAGA } \\
\text { R: CGGTACATCACCTCTGGCAACATT }\end{array}$ & XM_003444573.4 \\
\hline TGF- $\beta 1$ & $\begin{array}{l}\text { F: AAGAGGAGGAGGAATACTTTGCCA } \\
\text { R: GAAGCTCATTGAGATGACTTTGGG }\end{array}$ & XM_003459454 \\
\hline$T N F-\alpha$ & $\begin{array}{c}\text { F: CAGAAGCACTAAAGGCGAAGAACA } \\
\text { R: TTCTAGATGGATGGCTGCCTTG }\end{array}$ & NM_001279533 \\
\hline$E F-1 \alpha$ & $\begin{array}{l}\text { F: ATCAAGAAGATCGGCTACAACCCT } \\
\text { R: ATCCCTTGAACCAGCTCATCTTGT }\end{array}$ & XM_005469373.3 \\
\hline
\end{tabular}

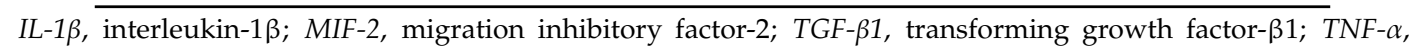
tumor necrosis factor- $\alpha ; E F-1 \alpha$, elongation factor- $1 \alpha$.

Real-time PCR (RT-PCR) was performed in a volume of $20 \mu \mathrm{L}$ containing $10 \mu \mathrm{L} 2 \times$ Ultra SYBR mixture (CW0957, Kangwei, China), $0.5 \mu \mathrm{L}$ of $10 \mathrm{mM}$ primers, $2.5 \mu \mathrm{L}$ of diluted first-standard cDNA template and $6.5 \mu \mathrm{L}$ of $\mathrm{H}_{2} \mathrm{O}$. The program cycling conditions were denaturation at $95^{\circ} \mathrm{C}$ for $30 \mathrm{~s}$, followed by 40 cycles of $94{ }^{\circ} \mathrm{C}$ for $15 \mathrm{~s}, 58{ }^{\circ} \mathrm{C}$ for $20 \mathrm{~s}, 72{ }^{\circ} \mathrm{C}$ for $20 \mathrm{~s}$, and a $0.5{ }^{\circ} \mathrm{C}$ per $5 \mathrm{~s}$ increment from $60^{\circ} \mathrm{C}$ to $95^{\circ} \mathrm{C}$. RT-PCR was analyzed in the CFX96 Real-Time PCR system (Bio-Rad, Richmond, $\mathrm{CA}, \mathrm{USA})$. The cycle time ( $\mathrm{Ct}$ ) values of different experimental treatments in hypersaline water were 
compared to their corresponding internal control and then converted to fold change by comparison with the freshwater treatment through the quantified method of $2^{-\Delta \Delta c t}$. CFX Manager ${ }^{\mathrm{TM}}$ Software (version 1.0) was used to study data visualization and relative quantification analysis.

\subsection{Intestinal Microbiota Analysis in Nile tilapia}

Intestinal contents were used for bacterial composition analysis in Nile tilapia under four experimental treatments. The total microbiota DNA was isolated with an E.Z.N.A.TM soil DNA kit according to the manufacturer's instructions. DNA quality was assessed by PCR amplification of the bacterial 16S rRNA genes, and the quantity was measured using a NanoDrop spectrophotometer (Thermo, Wilmington, DE, USA). The V3-V4 region of the bacterial 16S ribosomal RNA genes was amplified by PCR using the primers 338F (ACTCCTACGGGAGGCAGCA) and 806R (GGACTACHVGGGTWTCTAAT). The PCR reactions were performed in a $25 \mu \mathrm{L}$ mixture containing $5 \mu \mathrm{L}$ of $5 \times$ reaction buffer, $5 \mu \mathrm{L}$ of $5 \times$ GC buffer, $2 \mu \mathrm{L}$ of $2.5 \mathrm{mM}$ dNTPs, $1 \mu \mathrm{L}$ of forward primer $(10 \mu \mathrm{M}), 1 \mu \mathrm{L}$ of reverse primer $(10 \mu \mathrm{M}), 2 \mu \mathrm{L}$ of DNA template, $8.75 \mu \mathrm{L}$ of $\mathrm{H}_{2} \mathrm{O}$, and $0.25 \mu \mathrm{L}$ of Q5 high-fidelity DNA polymerase (M0419S, New England BioLabs, Beijing, China). The PCR reaction conditions were as follows: $98^{\circ} \mathrm{C}$ for $2 \mathrm{~min}$, followed by 26 cycles of denaturation at $98^{\circ} \mathrm{C}$ for $15 \mathrm{~s}$, annealing at $55^{\circ} \mathrm{C}$ for $30 \mathrm{~s}$, extension at $72{ }^{\circ} \mathrm{C}$ for $30 \mathrm{~s}$, and extension at $72{ }^{\circ} \mathrm{C}$ for $5 \mathrm{~min}$. The purified PCR products were subjected to the Illumina MiSeq PE300 platform (Shanghai Personal Biotechnology Co., Ltd., Shanghai, China), generating paired-end reads. Low-quality sequences with a length below $150 \mathrm{bp}$, and mononucleotide repeats over $8 \mathrm{bp}$, average Phred scores $<20$ and with ambiguous bases were removed. The sequences obtained in the present study can be downloaded from Sequence ReadArchive (SRA) with the accession number PRJNA433775.

Operational taxonomic units (OTUs) were clustered according to the similarity cutoff of $97 \%$ using UPARSE (version $7.1 \mathrm{http}: / /$ drive5.com/uparse/) (Edgar, 2013). The most abundant sequence in the OTUwas selected as the representative sequence, followed by taxonomic assignment in the Greengenes database (release 13.8) using the confidence threshold of 70\%. QIIME calculated alpha diversity indices. Partial least squares discriminant analysis (PLS-DA) was used to test classification model influence by $\mathrm{R}$ software. A Venn diagram was constructed to identify the same and unique OTUs. Intestinal microbiota interspecies interaction among dominant classes with abundance in the top 50 of four treatments was calculated using Mothur, constructing the interspecies interaction network for the dominant class with Rho $>0.6$ and $p<0.01$. The network properties were calculated and visualized with Gephi.

\subsection{Statistical Analysis}

Statistical analysis was performed using SPSS statistics 20 (IBM, Armonk, NY, USA). All data were mean \pm standard error (mean \pm S.E.). Significant differences in relative spleen weight and intestinal microbiota richness and diversity were analyzed by one-way analysis of variance (ANOVA) in tilapia among all treatments. Data on hematology and mRNA expression in tilapia in brackish water were analyzed by ANOVA. Student's t-test was used to analyze significant differences in hematological data and mRNA expression in tilapia between freshwater and brackish water. A total of 37 OTUs were selected for heatmap analysis using Student's t-test with subsequent Bonferroni correction. A single asterisk "** represents significant differences $(p<0.05)$, and double asterisks "***" represent extremely-significant differences $(p<0.01)$.

\section{Results}

\subsection{Survival, Growth Performance, and Relative Spleen Weight}

There were no significant differences in weight gain (WG) or survival among all treatments. Tilapia in hypersaline water showed a significantly-higher relative spleen weight (RSW) than those 
in freshwater $(p<0.05)$. The supplementation of $\beta$-glucan significantly reduced RSW in tilapia in brackish water $(p<0.05)$ (Table 3$)$.

Table 3. Growth performance, survival, and relative spleen weight of Oreochromis niloticus fed diets with different $\beta$-glucan percentages under two salinities for 8 weeks.

\begin{tabular}{ccccc}
\hline \multirow{2}{*}{ Items } & \multirow{2}{*}{ Freshwater } & \multicolumn{3}{c}{ Brackish Water (16 psu)- $\beta$-glucan (\%) } \\
\cline { 3 - 5 } & & $\mathbf{0}$ & $\mathbf{0 . 2}$ & $\mathbf{0 . 4}$ \\
\hline Initial weight & $1.27 \pm 0.01$ & $1.28 \pm 0.01$ & $1.28 \pm 0.01$ & $1.27 \pm 0.01$ \\
Final weight & $38.03 \pm 2.86$ & $41.50 \pm 1.53$ & $38.67 \pm 2.29$ & $38.40 \pm 2.70$ \\
Weight gain (\%) & $2974.75 \pm 226.02$ & $3235.35 \pm 109.63$ & $3025.67 \pm 172.76$ & $3008.85 \pm 206.30$ \\
Relative spleen weight (\%) & $0.29 \pm 0.01^{\mathrm{b}}$ & $0.37 \pm 0.03^{\mathrm{c}}$ & $0.24 \pm 0.09^{\mathrm{a}}$ & $0.23 \pm 0.02^{\mathrm{a}}$ \\
Survival (\%) & 100 & 100 & 100 & 100 \\
\hline
\end{tabular}

Values of initial weight and final weight are means of three measurements. Values of relative spleen weight are means of 15. Different superscript letters indicate significant differences within the same row (c indicated the highest value) $(p<0.05)$.

\subsection{Hematological Parameters}

Brackish water significantly increased RBC, HCT, RDW, PLT, and PCT in the blood of tilapia $(p<0.05)$. Tilapia fed diets with $\beta$-glucan showed significantly-lower RBC, HCT, RDW, PLT, and PCT than tilapia in brackish water fed the basal diet $(p<0.05)$ (Figure 1).

A
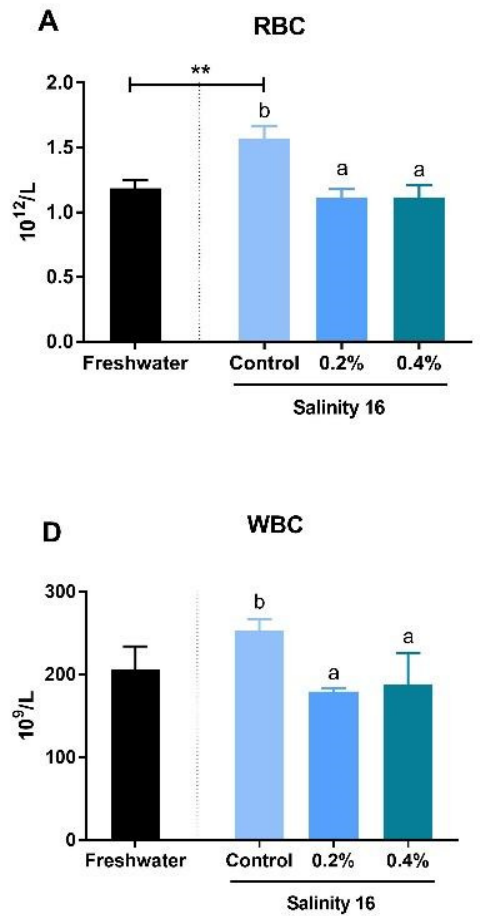
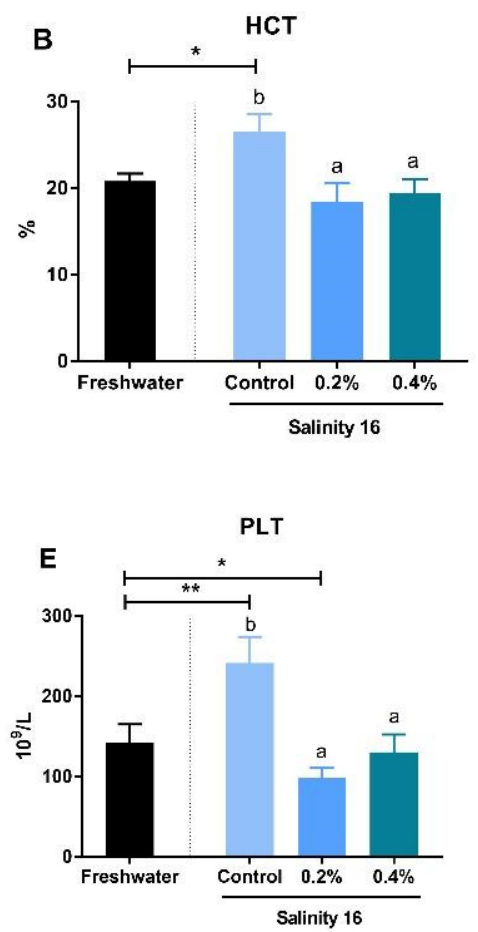
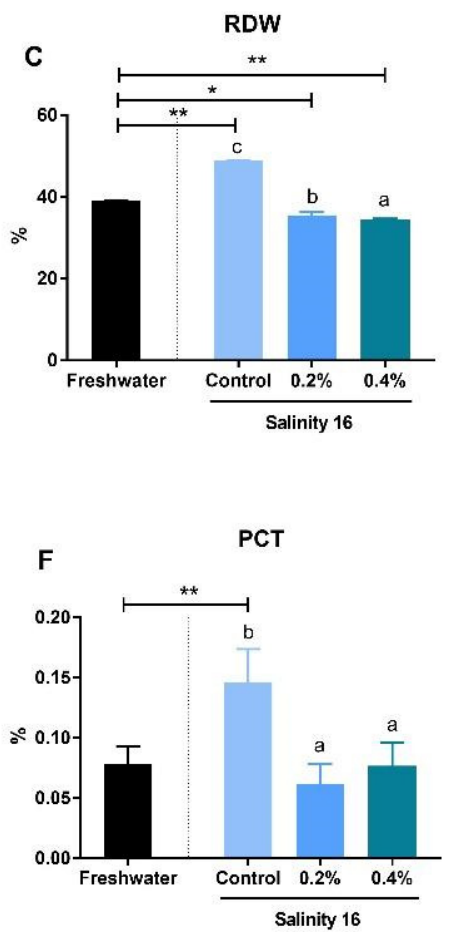

Figure 1. Effects of $\beta$-glucan supplementation on hematology in O. niloticus in freshwater and brackish water. Values are represented as mean \pm SE. A single asterisk $\left(^{*}\right)$ indicates a significant difference $(p<0.05)$, and two asterisks $\left.{ }^{* *}\right)$ indicate an extremely-significant difference $(p<0.01)$. (A) red blood cell count (RBC); (B) hematocrit (HCT); (C) red cell distribution width (RDW); (D) white blood cell count (WBC); (E) platelet count (PLT); and (F) plateletcrit (PCT). Different letters with a-c indicated significant differences among three treatments in 16 salinity water $(p<0.05)$.

\subsection{Gene Expression of Immune-Inflammatory Cytokines}

Tilapia in brackish water exhibited significantly-higher gene expression of TNF- $\alpha$, TGF- $\beta$, and IL-1 $\beta$ in the spleen than in freshwater $(p<0.05)$. Supplementation with $\beta$-glucan significantly reduced the 
gene expression of these immune genes $(p<0.05)$ (Figure 2A,B,D). The supplementation of $\beta$-glucan significantly decreased gene expression of TNF- $\alpha$ in a dose-dependent manner. In the intestine, gene expression of MIF-2 and $I L-1 \beta$ was significantly increased in a brackish water environment $(p<0.05)$. These increments can be alleviated in tilapia when fed diets with $\beta$-glucan (Figure 3C,D). TGF- $\beta$ expression in the intestine of tilapia fed the basal diet and the $0.2 \% \beta$-glucan diets in brackish water was significantly higher than that in freshwater $(p<0.05)$ (Figure 3B). However, the gene expression of TNF- $\alpha$ was significantly higher in tilapia fed diets with $\beta$-glucan in brackish water than in freshwater $(p<0.05)$ (Figure 3A). In the head kidney, the TNF- $\alpha$ expression of tilapia in brackish water was significantly higher than that in tilapia in freshwater $(p<0.05)$. Tilapia in brackish water fed diets with $\beta$-glucan showed significantly-higher gene expression of $I L-1 \beta$ than in freshwater $(p<0.05)$ (Figure 4).

\section{Spleen}
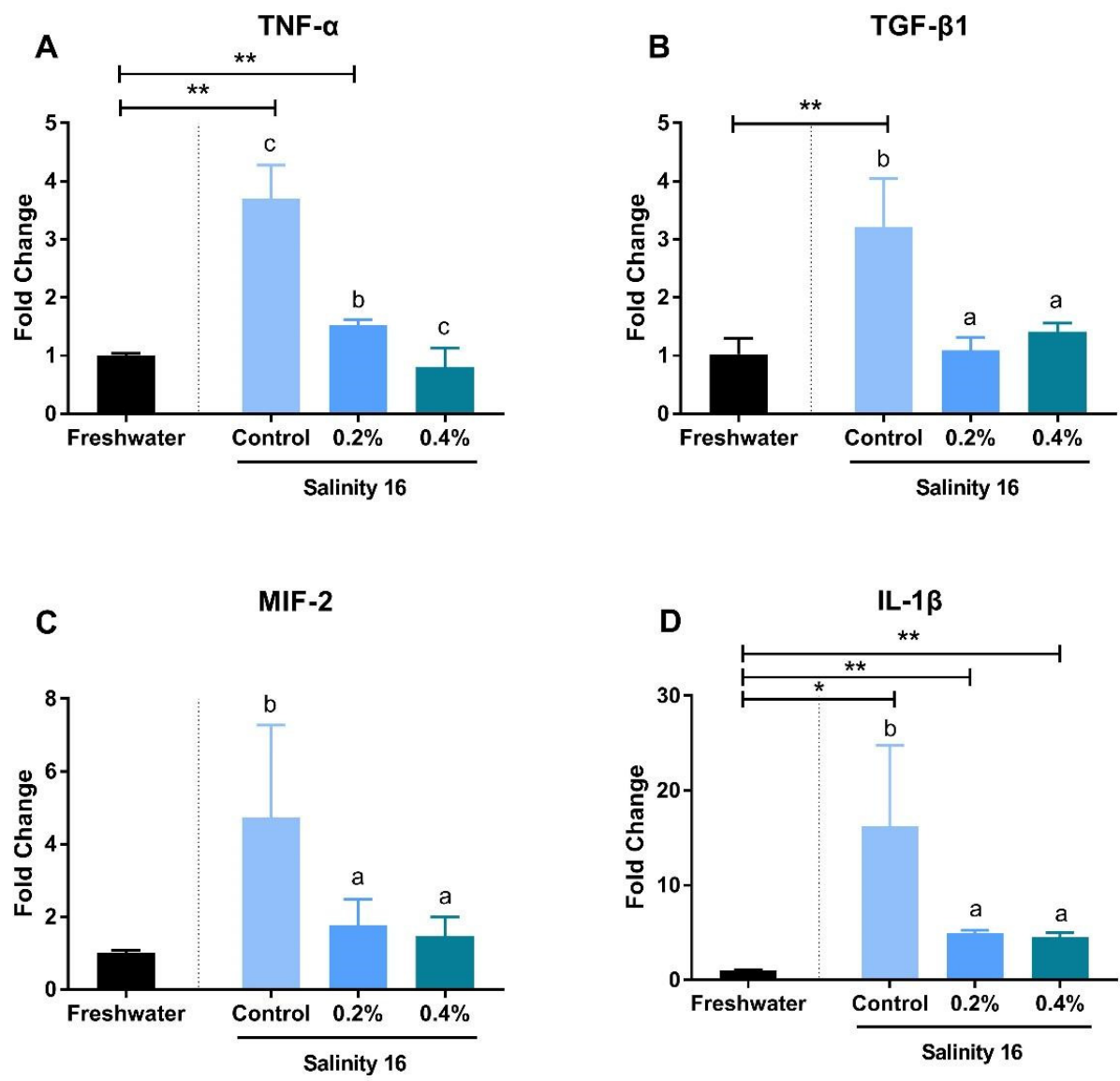

Figure 2. The gene expression of TNF- $\alpha$ (A), TGF- $\beta 1$ (B), MIF-2 (C), and $I L-1 \beta$ (D) in the spleen of $O$. niloticus fed diets with $\beta$-glucan in freshwater and brackish water. A single asterisk $\left(^{*}\right)$ indicates a significant difference $(p<0.05)$ and two asterisks $(* *)$ indicate an extremely-significant difference $(p<0.01)$. Different letters with a-c indicated significant differences among three treatments in 16 salinity water $(p<0.05)$. 


\section{Intestine}
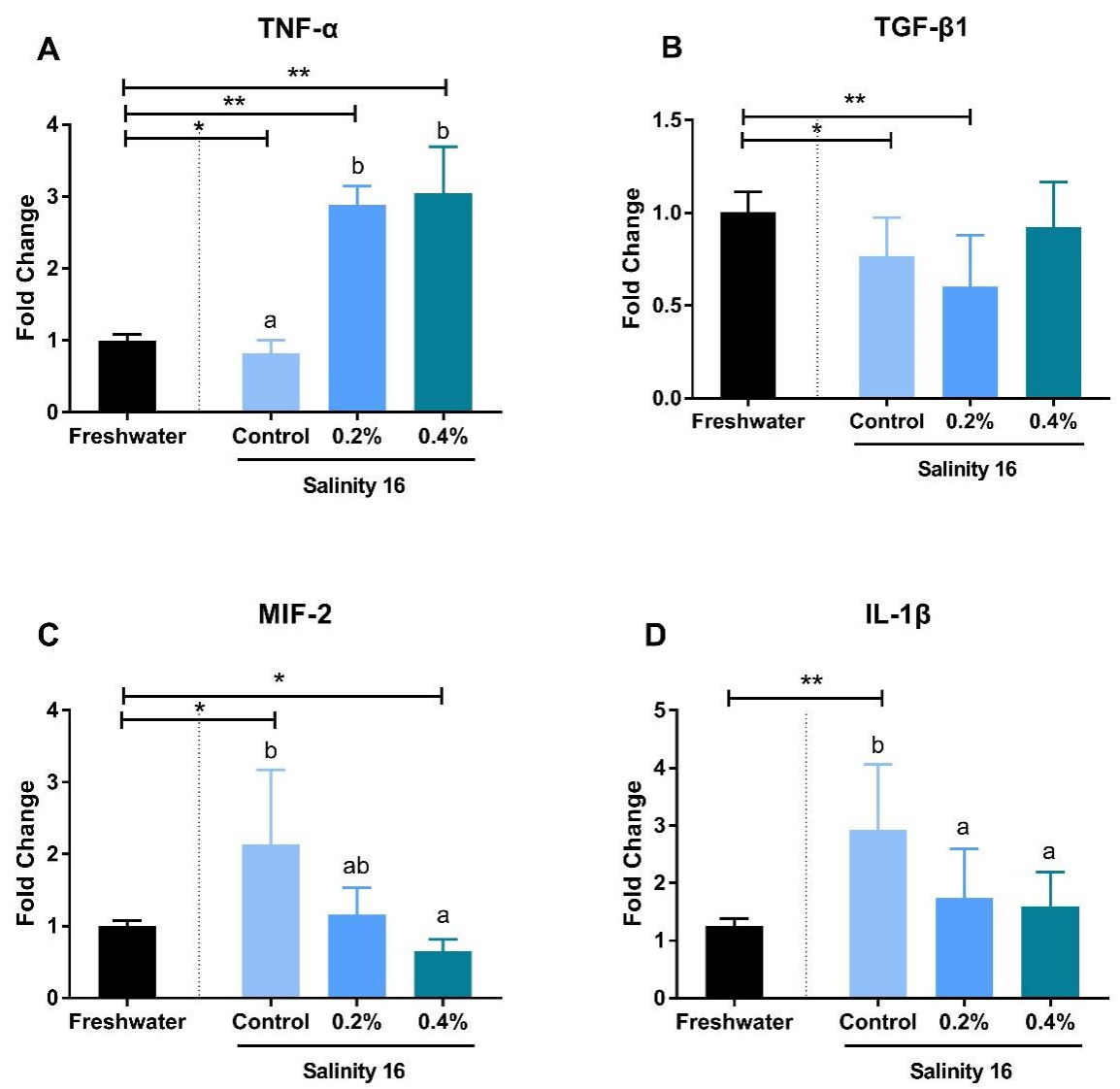

Figure 3. The gene expression of TNF- $\alpha$ (A), TGF- $\beta 1$ (B), MIF-2 (C), and $I L-1 \beta$ (D) in the intestine of $O$. niloticus fed diets with $\beta$-glucan in freshwater and brackish water. A single asterisk $\left(^{*}\right)$ indicates a significant difference $(p<0.05)$, and two asterisks $\left(^{* *}\right)$ indicate an extremely significant difference $(p<0.01)$. Different letters with a,b indicated significant differences among three treatments in 16 salinity water $(p<0.05)$.

\section{Head kidney}
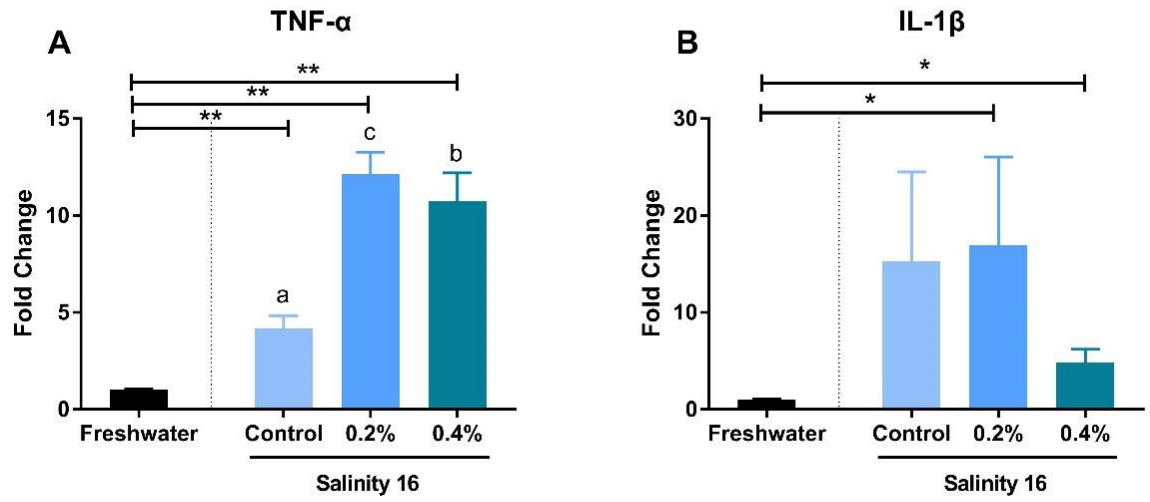

Figure 4. The gene expression of TNF- $\alpha(\mathbf{A})$ and $I L-1 \beta$ (B) in the head kidney of $O$. niloticus fed diets with $\beta$-glucan in freshwater and brackish water. A single asterisk $\left(^{*}\right)$ indicates a significant difference $(p<0.05)$, and two asterisks $\left.{ }^{* *}\right)$ indicate an extremely-significant difference $(p<0.01)$. Different letters with a-c indicated significant differences among three treatments in 16 salinity water $(p<0.05)$. 


\subsection{Differences in Bacterial Community Composition, Diversity, and Structure}

A total of 351,714 high-quality sequences were obtained from the intestinal microbiota with an average of 87,929 sequences per sample. Microbiota richness of Chao 1 and Ace ranged from 564.00 to 939.67 and from 564.11 to 939.67, respectively. Diversity of Shannon and Simpson ranged from 5.46 to 7.02 and from 0.93 to 0.97 , respectively (Table 4). Supplementation with $0.4 \% \beta$-glucan significantly reduced Chao 1, ACE Shannon, and Simpson indexes in the intestine as compared with those in tilapia fed the basal diet in brackish water $(p<0.05)$. Although $0.2 \% \beta$-glucan addition in diets also reduced intestinal microbiota richness and diversity as compared with absence of supplementation in the basal diet in brackish water, there was no significant difference between these two treatments.

Table 4. Summary of diversity index (Shannon and Simpson) and estimated OTU richness (Chao 1 and ACE) for intestinal bacterial diversity analysis of Oreochromis niloticus fed diets with different $\beta$-glucan percentages under two salinities for 8 weeks.

\begin{tabular}{ccccc}
\hline \multirow{2}{*}{ Items } & \multirow{2}{*}{ Freshwater } & \multicolumn{3}{c}{ Brackish Water (16 psu)- $\beta$-glucan (\%) } \\
\cline { 3 - 5 } & & $\mathbf{0}$ & $\mathbf{0 . 2}$ & $\mathbf{0 . 4}$ \\
\hline Richness estimate & & & & \\
Chao 1 & $782.01 \pm 138.12^{\mathrm{ab}}$ & $939.67 \pm 63.50^{\mathrm{b}}$ & $758.00 \pm 125.74^{\mathrm{ab}}$ & $564.00 \pm 16.07^{\mathrm{a}}$ \\
ACE & $782.30 \pm 138.15^{\mathrm{ab}}$ & $939.67 \pm 63.57^{\mathrm{b}}$ & $758.11 \pm 16.06^{\mathrm{ab}}$ & $564.11 \pm 16.06^{\mathrm{a}}$ \\
& & & & \\
Diversity estimators & & & \\
Shannon & $6.10 \pm 0.13^{\mathrm{ab}}$ & $7.02 \pm 0.40^{\mathrm{b}}$ & $6.01 \pm 0.71^{\mathrm{ab}}$ & $5.46 \pm 0.11^{\mathrm{a}}$ \\
Simpson & $0.94 \pm 0.01^{\mathrm{ab}}$ & $0.97 \pm 0.01^{\mathrm{b}}$ & $0.94 \pm 0.02^{\mathrm{ab}}$ & $0.93 \pm 0.01^{\mathrm{a}}$ \\
\hline
\end{tabular}

All data are represented as mean \pm S.E. $(n=3)$. Different superscript letters indicate significant differences within the same row (b indicates the higher value) $(p<0.05)$.

The top 20 taxa of relative abundance were differentiated by letters in the graph (outer layers to inner layers in the order from phylum to genus) (Figure 5A). Proteobacteria showed the highest abundance, followed by Actinobacteria, Firmicutes and Bacteroidetes, which were the dominant bacteria in the intestine across all treatments.

In the Venn diagram, there were 377 OTUs shared in tilapia among four treatments. Compared with the tilapia intestinal microbiota in freshwater (648 OTUs), there were 933 in 16 psu-0\% $\beta$-glucan, 473 in 16 psu- $0.2 \% \beta$-glucan, and 264 unique OTUs in 16 psu- $0.4 \% \beta$-glucan (Figure $5 \mathrm{~B}$ ). Supplementation with dietary $\beta$-glucan reduced the quantity of unique OTUs in tilapia as compared with the diet without $\beta$-glucan supplementation in freshwater and brackish water.

As shown by PLS-DA (partial least squares discriminant analysis) (Figure 5C), the distributions of bacterial communities in tilapia in freshwater and brackish water were distinguishable and showed a far coordinate distance. Supplementation with $\beta$-glucan reduced the coordinate distance, making it closer to that of the freshwater control, especially in the case of $0.4 \% \beta$-glucan treatment. There was an obvious overlap of the bacteria community distributions of tilapia in brackish water fed diets with $0.2 \%$ and $0.4 \% \beta$-glucan.

The heatmap analysis included 37 OTUs (Figure 6). Moraxella and Leuzea decreased significantly in tilapia in brackish water as compared with those in freshwater $(p<0.05)$. The abundances of Thermoactinomycetacae, Parachlamydiaceae, Caldilineaceae, Solirubrobacteraceae, Microbacteriaceae, and Phyllobacteriaceae were significantly lower in tilapia fed $0.2 \% \beta$-glucan $(p<0.05)$ in brackish water than in freshwater. Tilapia fed 0.2 and $0.4 \% \beta$-glucan exhibited significantly higher Lactobacillus, Phycicoccus and Collinsella than those in freshwater $(p<0.05)$. Meanwhile, Aeromonadaceae and Rikenellaceae showed a significantly-higher abundance in tilapia fed $0.2 \% \beta$-glucan than those in freshwater $(p<0.01)$. Finegoldia and Sediminibacterium exhibited significantly higher abundance in tilapia fed $0.4 \% \beta$-glucan than in freshwater $(p<0.05)$. Compared to tilapia fed the basal diet in brackish water, $0.4 \% \beta$-glucan supplementation significantly increased Nitrospira and Streptomyces richness in tilapia $(p<0.05)$. 
A

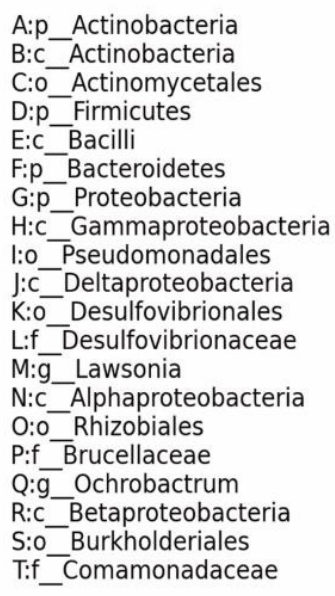

A:p_Actinobacteria

B:C-Actinobacteria

C:O Actinomycetales

D:p_Firmicutes

E:c-Bacilli

F:p_Bacteroidetes

G:p Proteobacteria

$\mathrm{H}: \mathrm{c}$ _Gammaproteobacteria

I:o_Pseudomonadales

J:c- Deltaproteobacteria

K:O- Desulfovibrionales

L:f_Desulfovibrionaceae

M: $\bar{g}$ Lawsonia

$\mathrm{N}: \mathrm{C}$-Alphaproteobacteria

0:0 Rhizobiales

P:f Brucellaceae

Q:g__ochrobactrum

R:c Betaproteobacteria

S:O-Burkholderiales

T:f_Comamonadaceae

B

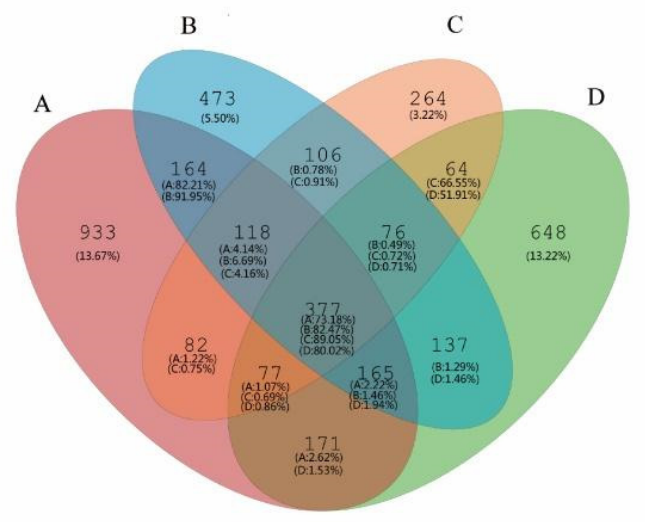

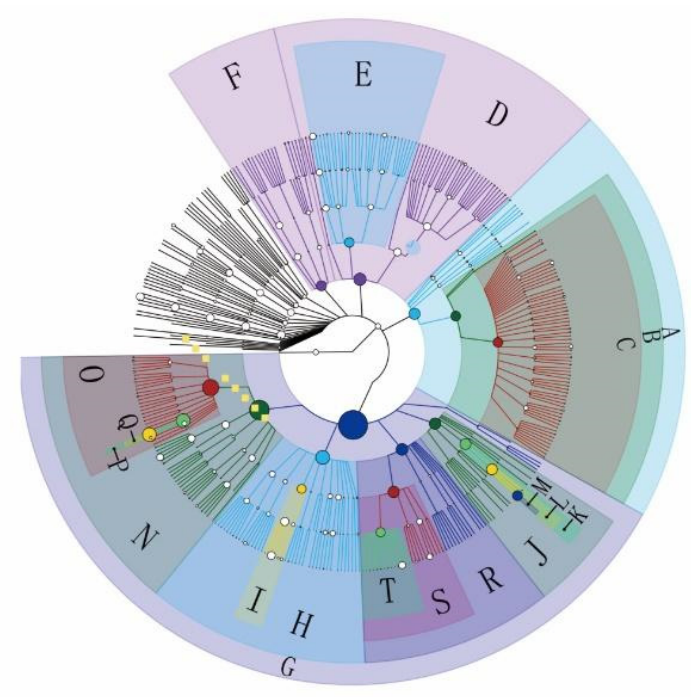

C

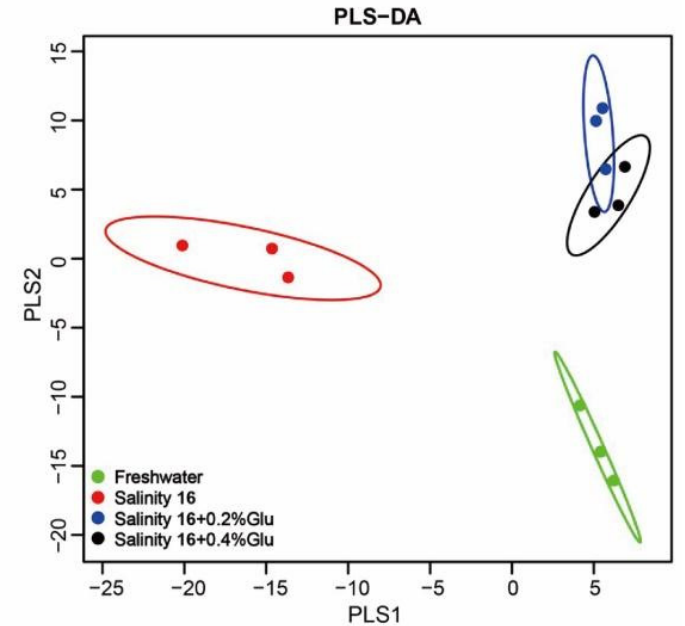

Figure 5. Cladogram (top 20), Venn diagram, and partial least squares discrimination analysis (PLS-DA) diagram of the intestinal microbiota in O. niloticus fed diets with $\beta$-glucan in freshwater and brackish water. (A) Cladogram of the intestinal microbiota displaying the top 20 components as inferred by GraPhlAn. Node size is proportional to the average abundance. Color indicates the relative concentration of the clusters. (B) Venn diagram showing the distribution of all OTUs shared and unique in $O$. niloticus reared in different environmental salinity conditions and fed diets with or without $\beta$-glucan $(0,0.2 \%$, and $0.4 \%)$. The percentage indicates the ratio of correlated OTUs in the total sequences of each treatment. A: $16 \mathrm{psu}, \mathrm{B}: 16 \mathrm{psu}+0.2 \% \beta$-glucan, C: $16 \mathrm{psu}+0.4 \% \beta$-glucan, D: freshwater. (C) PLS-DA discriminant analysis of intestinal microorganisms in O. niloticus under different environmental salinity conditions and fed diets with or without $\beta$-glucan $(0,0.2 \%$, and $0.4 \%)$. Each dot represents a sample, the points with the same color belong to the same group, and the marked points of groups are marked with ellipses. If the samples belonging to the same treatment are closer to each other, and the distance between the different treatment points is farther, the classification model will be more reliable. 


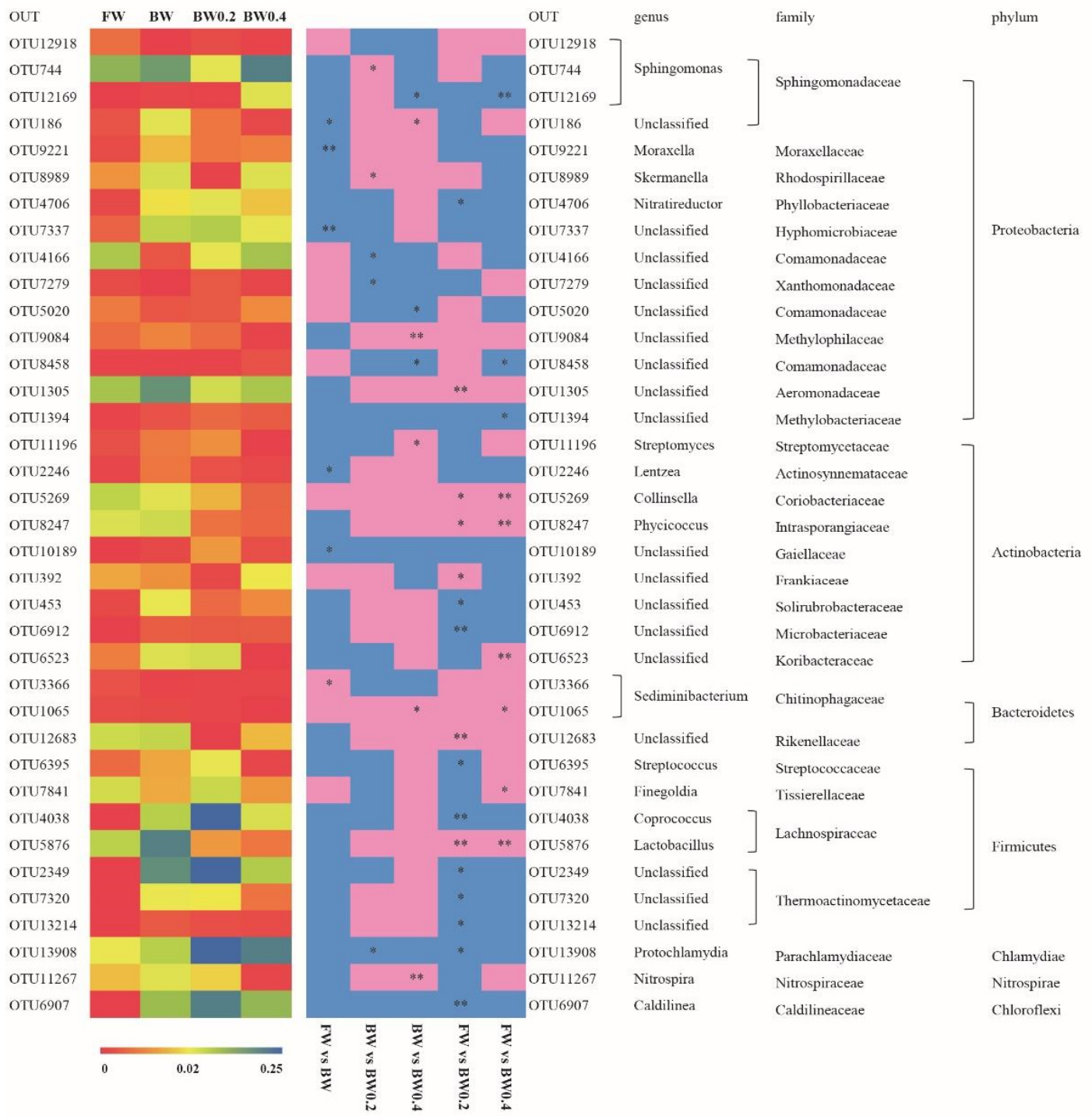

Figure 6. Heatmap analysis of 37 OTUs. The left heatmap includes the color bar of each OTU average value of three samples in each treatment. The right heatmap includes the color bars representing the difference of OTU in O. niloticus between two treatments. The pink bar suggests that the abundance of OTUs is higher and the blue bar suggests that the abundance of OTUs is lower. A single asterisk $\left(^{*}\right)$ indicates a significant difference $(p<0.05)$, and two asterisks $\left({ }^{* *}\right)$ indicate an extremely-significant difference $(p<0.01)$. The taxonomy of the OTUs (genus, family, and phylum) is depicted on the figure's right. FW denotes freshwater; BW denotes brackish water; BW 0.2 and BW 0.4 denote brackish water with $0.2 \%$ and $0.4 \% \beta$-glucan, respectively.

\subsection{Intestinal Microbiota Interspecies Interaction}

The interspecies interaction network was analyzed to evaluate the influence of environmental salinity and dietary $\beta$-glucan supplementation on interspecies interactions among the intestinal microbiota. Compared to the freshwater control, the network in O. niloticus in brackish water was more complex and better connected. The networks were more complex when $\beta$-glucan supplementation was provided; a dose-dependent effect was exhibited (Figure 7). The topological properties also indicated that the average path in tilapia fed $\beta$-glucan was higher than that of tilapia fed the basal diet (Table 5). There were increases in edges, average degree, graph density, centralization, and heterogeneity in the intestinal microbiota when $\beta$-glucan was supplemented in diets. $\beta$-glucan supplementation at $0.4 \%$ significantly improved the negative association ratio with respect to the results under $0.2 \%$ $\beta$-glucan supplementation. 
A1

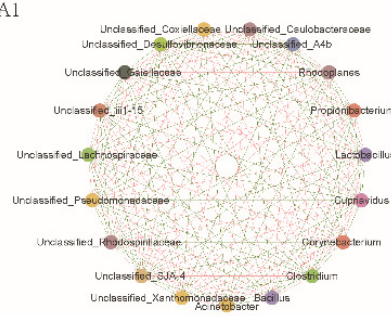

B1

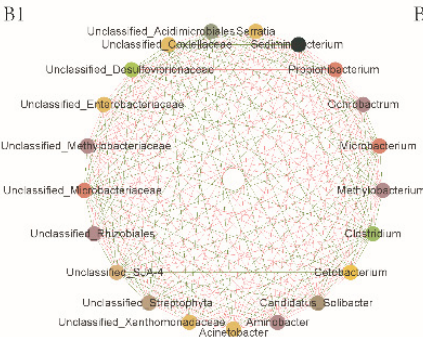

Cl

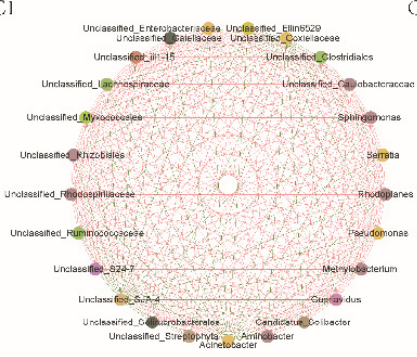

D1

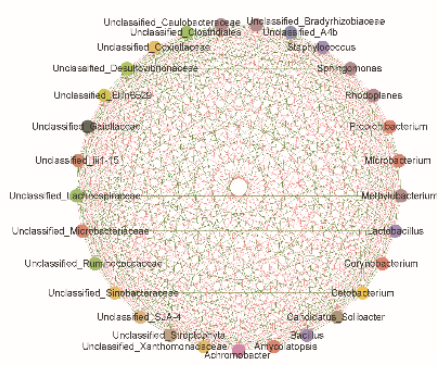

$\Lambda 2$
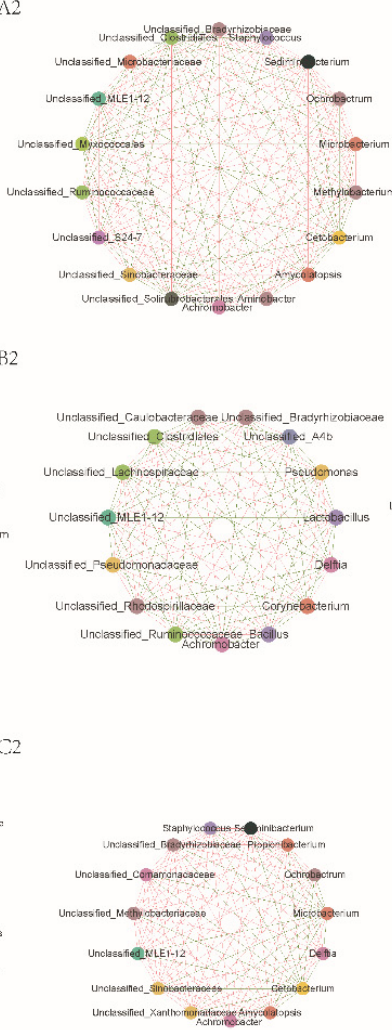

$\Gamma 2$

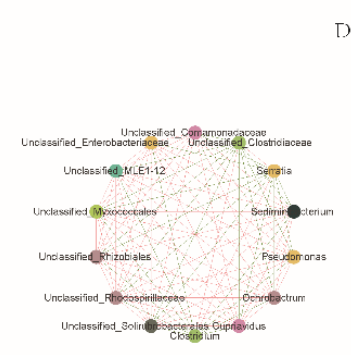

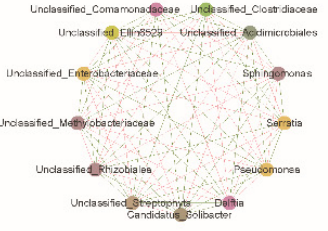

B3

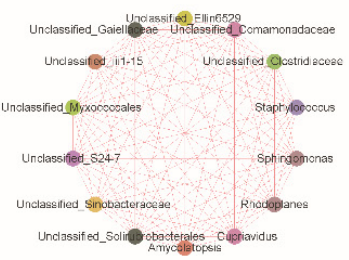

C3

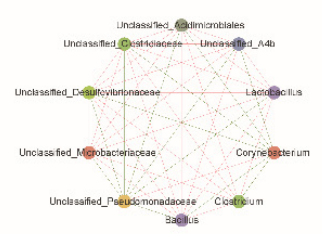

53

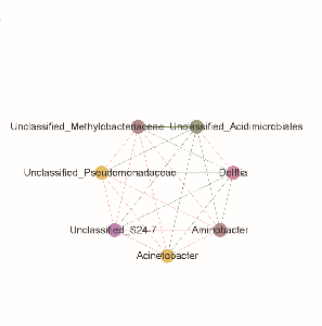

Class

${ }^{4} \mathrm{COd}-2$

Acidimicrobia

Acidobacteria- 6
Actinabacteria

- Alphaproteobacteria

- Anaerolineae

Anacillineae
Bacteroidia

Betaprotoobacter

Chloroplas

Clostridia
Deltaprotoobactoria
Ellin6529

Fusobacteriia

Gammaproteobacter

SNA.4

Solibacteres

Thermoleophilita

Figure 7. Interspecies interaction network of the intestinal microbiota for O. niloticus among four treatments. Each node represents a bacterial OTU. Node colors indicate OTUs affiliated with different major classes. The green edge indicates negative interaction, and the red edge indicates positive interaction between two individual nodes. (A1,A2,A3): freshwater; (B1,B2,B3): 16 psu; (C1,C2,C3): $16 \mathrm{psu}+0.2 \% \beta$-glucan; and (D1,D2,D3): $16 \mathrm{psu}+0.4 \% \beta$-glucan.

Table 5. Topological properties of the intestinal microbiota co-occurrence network.

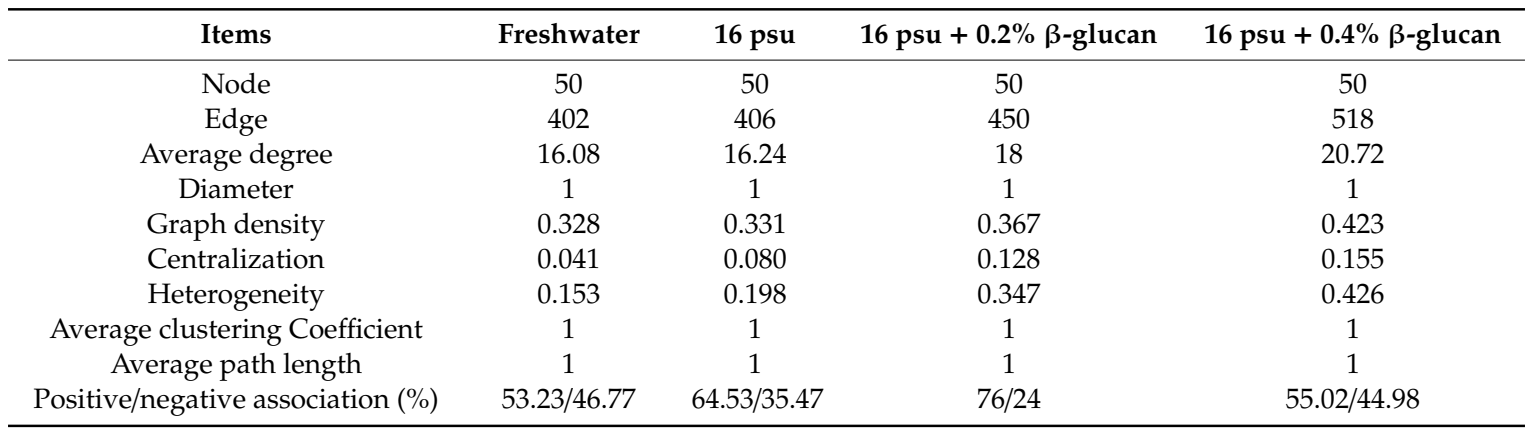




\section{Discussion}

As an immunostimulant, $\beta$-glucan is considered an effective reagent for enhancing the immune status of aquatic animals in aquaculture [37]. $\beta$-glucan supplementation in diets can significantly improve growth performance in various fish, such as Cyprinus carpio koi [38], Oncorhynchus mykiss [39], O. niloticus [40], and Apostichopus japonicas [41]. However, in the present study, weight gain was not improved by dietary $\beta$-glucan in tilapia in brackish water. In O. mossambicus, only $1 \% \beta$-glucan in the diet significantly increased weight gain after an 8-week cultivation [42]. Similar results were also found in Dicentrachus labrax [43], O. nilotics [44], and Carassius auratus by adding $\beta$-glucan [45]. Therefore, the supplementary dose of $\beta$-glucan in the diet has a key influence on growth performance, especially in a stressful environment.

Although no significant improvement in growth performance was observed in tilapia, the tissue damage was significantly alleviated by dietary $\beta$-glucan supplementation in this study. The enlargement of the spleen due to long-term hypersaline stress can be significantly improved by $\beta$-glucan supplementation in the diet regardless of concentrations. $\beta$-glucan $(0.1 \%)$ in the diet also can decrease RSW in O. niloticus under diazinon stress [46]. Cytologically, the spleen is the largest lymphoid organ and an immunocompetent organ in teleost that is rich in melano-macrophages for phagocytosis in the immune response [47]. The normal volume of the spleen is vital to physiological function in fish. Previous research indicated that fungal polysaccharides can activate the innate immune system by binding to receptors on macrophages to stimulate the phagocytosis index in vertebrates [48]. Therefore, the spleen can be recovered to a healthy status in tilapia after an 8-week $\beta$-glucan intake under a hyperosmotic environment.

In addition to its immune function role, the spleen also serves a hematopoietic function equivalent to erythropoiesis in the bone marrow until adulthood [47]. The hematological results indicated that the RBC count was significantly higher in fish fed the basal diet in brackish water than in freshwater. Long-term hyperosmotic stress can inhibit coagulation cascades in the spleen and result in an enlarged spleen in paraffin sections from O. niloticus [23]. $\beta$-glucan supplementation could significantly decrease HCT, RDW, PLT, and PCT in O. niloticus in brackish water. However, this result is at odds with previous studies where $\beta$-glucan increased WBC and RBC in Trachinotus ovatus [49], Rutilus Frisii kutum [19], and Labeo rohita [50]. It seems that the response of hematological indicators in fish fed $\beta$-glucan supplements depends on the condition of environmental stress.

Inflammatory cytokines exhibited a pattern of different gene expression in the spleen, intestine, and head kidney. In the spleen, the increase in TNF- $\alpha$ expression was significantly decreased by dietary $\beta$-glucan supplementation. TNF- $\alpha$ is produced primarily by monocytic lineage cells, such as macrophages and TNF- $\alpha$-activated macrophages, which can cause many autoimmune diseases [51]. In the spleen section, macrophage disappearance is reflected by the reduction of gene expression of TNF- $\alpha$ in tilapia fed $\beta$-glucan in brackish water. In macrophages, as a receptor, TNF- $\alpha$ can regulate the production of TGF- $\beta 1$ through the c-Jun NH2 terminal kinase pathway. However, this pathway in macrophages acts a negative autoregulatory loop in the control of TNF- $\alpha$-induced TGF- $\beta 1$ production [52]. Therefore, gene expression of TGF- $\beta 1$ also exhibited a significant decrease in the spleen of tilapia fed $\beta$-glucan in brackish water. TGF- $\beta 1$ in the intestine showed a different expression pattern compared to that in the spleen. $I L-1 \beta$ is a pro-inflammatory cytokine that can initiate and regulate the inflammatory process, as well as apoptosis and cell division processes, and this gene is important for stimulating effective innate host defenses, cell multiplication, phagocytosis, and nitric oxide production $[53,54]$. Supplementation with $\beta$-glucan can significantly suppress the expression of $I L-1 \beta$ in the spleen, intestine, and head kidney of tilapia. Similarly, $\beta$-glucan supplementation can also down-regulate the expression of $I L-1 \beta$ in the head kidney and intestine of Cyprinus carpio L [55]. The MIF has gained substantial attention as a pivotal upstream mediator of innate and adaptive immune responses and can serve as a biomarker for diseases with inflammatory reaction [56]. The gene expression of MIF in the intestine and spleen was decreased due to $\beta$-glucan intake in brackish water. $\beta$-glucan has a dual function of both pro-inflammatory mediator production and anti-inflammatory 
properties $[57,58]$. In the present study, the enhanced immune response in the spleen induced by environmental salinity could be significantly relieved by dietary $\beta$-glucan. However, pro-inflammatory indicators, such as TNF- $\alpha$ in the intestine and head kidney, were still significantly increased by the supplementation with $\beta$-glucan in brackish water.

The health status response of the intestine was also reflected in the results of the microbial community. $\beta$-glucan can be absorbed by the intestine and stimulate immune response [59]. It can be used as a probiotic fermentation substrate which is catabolized by anaerobic bacteria to produce SCFA, modulate the production of cytokines and chemokines, and improve systemic inflammation [60]. SCFA is also a vital nutrient substrate for mucosa and epithelial cells, improving intestinal epithelial cell proliferation and promoting peristalsis $[14,15]$. Intestinal microbiota richness and diversity estimators were decreased due to the supplementation of $\beta$-glucan, especially in tilapia fed $0.4 \%$ $\beta$-glucan. In Solea senegalensis, three different glucan diets all reduced microbiome species richness and diversity by oral intubation [61]. The reduction of richness and diversity was also reported in Apostichopus japonicus and C. carpio L fed $\beta$-glucan $[20,62]$. Similar results were found in L. vannamei fed $\beta$-glucan under salinity stress [12]. Although bacterial diversity and richness can play essential roles in maintaining intestinal ecological function, the vital effect still depends on the enrichment of certain beneficial species in the intestinal microbiota community, rather than diversity itself $[63,64]$. Additionally, PLS-DA indicated that $\beta$-glucan supplementation can modulate the intestinal microbiota community of tilapia, and the modulated community was similar to that in the freshwater control, especially in tilapia fed $0.4 \% \beta$-glucan. This is indicative that $\beta$-glucan supplementation in the diet can restore and benefit the intestinal microbiota environment in tilapia in brackish water.

With respect to the constituents of the intestinal microbiota at the genus level, $0.2 \%$ and $0.4 \%$ $\beta$-glucan supplementation significantly increased the abundance of Lactobacillus in tilapia. Lactic acid bacteria are beneficial to the fish intestinal ecosystem due to producing bacteriocins, lactic acid, and other antagonistic compounds to inhibit the amounts of some fish pathogens [65]. Previous research indicated that $\beta$-glucan is a fermentative substrate that enhances the proliferation of Lactobacillus in vitro [66]. Lactobacillus plantarum is an effective additive in the tilapia diet [67]. The dose of $0.4 \%$ $\beta$-glucan in the diet significantly increased the abundance of Nitrospiraceae in the intestine of tilapia as compared with the abundance observed in fish in brackish water fed the basal diet. This may present a close relationship with a low $\mathrm{pH}$ in the intestine due to high richness of Lactobacillus and Nitrospiraceae, which are more commonly found at a $\mathrm{pH}<2.0$ [68]. Phycicoccus and Collinsella also showed significantly-higher abundance in tilapia fed $\beta$-glucan. These two groups of microorganisms showed higher abundance in the intestine of Eriocheir sinensis and canines when fed diets with L-tryptophan and green tea polyphenols, respectively $[69,70]$. Compared to tilapia in brackish water fed a basal diet, $0.4 \% \beta$-glucan in the diet significantly increased the richness of Streptomyces in the intestine. Streptomyces fungus can produce chitinase in the intestine to inhibit pathogens [71]. Streptomyces cerevisiae $\beta$-glucan can also prevent airway hyperreactivity and pulmonary inflammation in a murine asthma model [72]. At the family level, $0.2 \% \beta$-glucan supplementation significantly decreased the abundance of Thermoactinomycetacae, Caldilineaceae, Solirubrobacteraceae, Microbacteriaceae and Phyllobacteriaceae in the intestine of tilapia as compared with those in the freshwater group. The Caldilineaceae abundance can be inhibited by resveratrol and oxytetracycline intake in tilapia and zebrafish, respectively [73-75]. Meanwhile, resveratrol can also increase the abundance of Firmicutes, just like $\beta$-glucan in tilapia [74]. Compared to the results without $\beta$-glucan supplementation in both freshwater and brackish water, $\beta$-glucan supplementation in the diet could increase the abundance of Rikenellaceae in the intestine of tilapia. The richness of Rikenellaceae is positively correlated with the inflammatory foci and the alleviation of intestinal barrier dysfunction [76]. At the phylum level, $0.4 \% \beta$-glucan significantly increased Firmicutes abundance in tilapia intestine compared with fish in brackish water fed a basal diet. Similar results were found in L. vannamei and Acipenser baerii fed $\beta$-glucan and arabinoxylan oligosaccharides, respectively [12,77]. 
The intestinal microbial communities of $O$. niloticus fed with $0.4 \% \beta$-glucan showed the highest average connectivity and most complex ecological networks among all the treatments. Interacting intestinal bacteria can achieve a dynamic balance in an organism, though they are still sensitive to environmental and nutritional factors [78]. In addition to the characteristics of ecological network complexity, intestinal microbial stability is also closely related to the forms of interspecific interaction with similar or complementary functions [79]. Positive interactions indicate complementation or cooperation, while negative interactions may show competition or predation between bacteria at the family level [80]. Supplementation with $0.2 \% \beta$-glucan can significantly increase the ratio of positive interaction, and the $0.4 \% \beta$-glucan supplementation can significantly increase the negative interactions of the intestinal microbiota in O. niloticus. Positive interactions can improve evolutionary stability when families are more likely to interact with other cooperators [81]. However, the intestinal microbiota may be more stable when the community is more competitive than cooperative. Therefore, $0.4 \% \beta$-glucan supplementation can provide a more stable intestinal microbial community in $O$. niloticus than $0.2 \% \beta$-glucan supplementation and the basic diet.

\section{Conclusions}

Dietary supplementation with $0.2 \%$ and $0.4 \% \beta$-glucan can significantly relieve the spleen enlargement and improve the immune function of $O$. niloticus in brackish water. Meanwhile, $\beta$-glucan intake (especially $0.4 \%$ concentration) also can optimize the intestinal microbiota, enhance the complex microbiota interactions of $O$. niloticus in brackish water and improve fish health.

Author Contributions: Data curation, C.X. and Y.S.; formal analysis, C.X., Y.S., and X.W.; methodology, Y.S., E.L., and L.C.; software, C.X., Y.S., and X.W.; supervision, E.L. and J.G.Q; writing-original draft, C.X. and Y.S.; writing-review and editing, C.X., J.G.Q., and E.L.; funding acquisition, E.L. and X.W. All authors have read and agreed to the published version of the manuscript.

Funding: This research was funded by grants from the Hainan Provincial Key Research and Development Program (ZDYF2019068), the National Natural Science Foundation of China (31802311), the Initial Fund from Hainan University for R \& D (KYQD(ZR)1736), and the Construction Project of Scientific Research Platforms of Hainan University (ZY2019HN09).

Conflicts of Interest: The authors declare no conflict of interest.

\section{References}

1. Vetvicka, V.J.; Vetvickova, J. Physiological effects of different types of $\beta$-glucan. Biomed. Pap. Med. Fac. Univ. Palacky Olomouc Czech. Repub. 2007, 151, 225-231. [CrossRef] [PubMed]

2. Goodridge, H.S.; Wolf, A.J.; Underhill, D.M. $\beta$-Glucan recognition by the innate immune system. Immunol. Rev. 2009, 230, 38-50. [CrossRef] [PubMed]

3. Cao, Y.; Sun, Y.; Zou, S.W.; Duan, B.C.; Sun, M.Y.; Xu, X.J. Yeast $\beta$-glucan suppresses the chronic inflammation and improves the microenvironment in adipose tissues of ob/ob mice. J. Agric. Food Chem. 2018, 66, 621-629. [CrossRef] [PubMed]

4. $\quad$ Chan, C.F.; Chan, W.K.; Sze, M.Y. The effects of $\beta$-glucan on human immune and cancer cells. J. Hematol. Oncol. 2009, 2, 25. [CrossRef] [PubMed]

5. Pilarski, F.; de Oliveira, C.A.F.; de Souza, F.P.B.D.; Zanuzzo, F.S. Different $\beta$-glucans improve the growth performance and bacterial resistance in Nile tilapia. Fish Shellfish Immunol. 2017, 70, 25-29. [CrossRef]

6. Dawood, M.A.O.; Eweedah, N.M.; Moustafa, E.M.; Shahin, M.G. Effects of aspergillus oryzae and $\beta$-glucan on growth and oxidative and immune responses of Nile tilapia, Oreochromis niloticus. Probiotics Antimicro. 2019, 425, 9. [CrossRef]

7. Udayangani, R.; Dananjaya, S.; Fronte, B.; Kim, C.H.; Lee, J.; Zoysa, M.D. Feeding of nano scale oats $\beta$-glucan enhances the host resistance against Edwardsiella tarda and protective immune modulation in zebrafish larvae. Fish Shellfish Immunol. 2017, 60, 72-77. [CrossRef] 
8. Dawood, M.A.O.; Koshio, S.; Ishikawa, M.; Yokoyama, S.; El Basuini, M.F.; Hossain, M.S.; Nhu, T.H.; Moss, A.S.; Dossou, S.; Wei, H. Dietary supplementation of $\beta$-glucan improves growth performance, the innate immune response and stress resistance of red sea bream, Pagrus major. Aquac. Nurt. 2017, 23, 148-159. [CrossRef]

9. Chen, D.; Ainsworth, A.J. Glucan administration potentiates immune defence mechanisms of channel catfish, Ictalurus punctatus Rafinesque. J. Fish. Dis. 2006, 15, 295-304. [CrossRef]

10. Ai, Q.H.; Mai, K.S.; Zhang, L.; Tan, B.P.; Zhang, W.B.; Xu, W.; Li, H.T. Effects of dietary $\beta-1,3$ glucan on innate immune response of large yellow croaker, Pseudosciaena crocea. Fish Shellfish Immunol. 2007, 22, 394-402. [CrossRef]

11. Murthy, H.S.; Li, P.; Lawrence, A.L.; Gatlin, D.M. Dietary $\beta$-glucan and nucleotide effects on growth, survival and immune responses of pacific white shrimp, Litopenaeus vannamei. J. Appl. Aquac. 2009, 21, 160-168. [CrossRef]

12. Li, H.F.; Xu, C.; Zhou, L.; Dong, Y.F.; Su, Y.J.; Wang, X.D.; Jian, G.Q.I.N.; Chen, L.Q.; Li, E.C. Beneficial effects of dietary beta-glucan on growth and health status of Pacific white shrimp Litopenaeus vannamei at low salinity. Fish Shellfish Immunol. 2019, 91, 315-324. [CrossRef] [PubMed]

13. Jayachandran, M.; Chen, J.L.; Chung, S.S.M.; Xu, B.J. A critical review on the impacts of $\beta$-glucans on gut microbiota and human health. J. Nutr. Bio. 2018, 61, 101-110. [CrossRef] [PubMed]

14. Sima, P.; Vannucci, L.; Vetvicka, V. ß-glucans and cholesterol (Review). Int. J. Mol. Med. 2018, 41, $1799-1808$. [CrossRef] [PubMed]

15. Scott, K.P.; Gratz, S.W.; Sheridan, P.O.; Flint, H.J.; Duncan, S.H. The influence of diet on the gut microbiota. Pharmacol. Res. 2013, 69, 52-60. [CrossRef] [PubMed]

16. Li, E.C.; Xu, C.; Wang, X.D.; Wang, S.F.; Zhao, Q.; Zhang, M.L.; Jian, G.Q.I.N.; Chen, L.Q. Gut microbiota and its modulation for healthy farming of Pacific white shrimp, Litopenaeus vannamei. Rev. Fish. Sci. Aquac. 2018, 26, 381-399. [CrossRef]

17. Jung-Schroers, V.; Adamek, M.; Jung, A.; Harris, S.; Harris, S.; Dóza, Ö.-S.; Baumer, A.; Steinhagen, D. Feeding of $\beta-1,3 / 1,6$-glucan increases the diversity of the intestinal microflora of carp (Cyprinus carpio). Aquacult Nutr. 2015, 22, 1026-1039. [CrossRef]

18. Miest, J.J.; Arndt, C.; Adamek, M.; Steinhagen, D.; Reusch, T.B.H. Dietary $\beta$-glucan (MacroGard ${ }^{\circledR}$ ) enhances survival of first feeding turbot (Scophthalmus maximus) larvae by altering immunity, metabolism and microbiota. Fish Shellfish Immunol. 2016, 48, 94-104. [CrossRef]

19. Rufchaie, R.; Hoseinifar, S.H. Effects of dietary commercial yeast glucan on innate immune response, hematological parameters, intestinal microbiota and growth performance of white fish (Rutilus frisii kutum) fry. Croat. J. Fisheries. 2014, 72, 156-163. [CrossRef]

20. Kühlwein, H.; Emery, M.J.; Rawling, M.D.; Harper, G.M.; Merrifield, S.J.; Davies, S.J. Effects of a dietary $\beta$ - $(1,3)(1,6)$-D-glucan supplementation on intestinal microbial communities and intestinal ultrastructure of mirror carp (Cyprinus carpio L.). J. Appl. Microbiol. 2013, 115, 1091-1106. [CrossRef]

21. Wongsasak, U.; Chaijamrus, S.; Kumkhong, S.; Boonanuntanasarn, S. Effects of dietary supplementation with $\beta$-glucan and synbiotics on immune gene expression and immune parameters under ammonia stress in Pacific white shrimp. Aquaculture 2015, 436, 179-187. [CrossRef]

22. Brocker, C.; Thompson, D.C.; Vasilis, V. The role of hyperosmotic stress in inflammation and disease. Biomol. Concepts 2012, 3, 345-364. [CrossRef] [PubMed]

23. Xu, C.; Li, E.C.; Suo, Y.T.; Su, Y.J.; Lu, M.H.; Zhao, Q.; Jian, G.Q.I.N.; Chen, L.Q. Histological and transcriptomic responses of two immune organs, the spleen and head kidney, in Nile tilapia (Oreochromis niloticus) to long-term hypersaline stress. Fish Shellfish Immunol. 2018, 76, 48-57. [CrossRef] [PubMed]

24. Zapata, A.; Diez, B.; Cejalvo, T.; Gutiérrezde, F.C.; Cortés, A. Ontogeny of the immune system of fish. Fish Shellfish Immunol. 2006, 20, 126-136. [CrossRef]

25. Fishelson, L. Cytomorphological alterations of the thymus, spleen, head-kidney, and liver in cardinal fish (Apogonidae, Teleostei) as bioindicators of stress. J. Morphol. 2006, 267, 57-69. [CrossRef]

26. Jiang, I.F.; Kumar, V.B.; Lee, D.N.; Weng, C.F. Acute osmotic stress affects Tilapia (Oreochromis mossambicus) innate immune responses. Fish Shellfish Immunol. 2008, 25, 841-846. [CrossRef]

27. Tellez-Bañuelos, M.C.; Santerre, A.; Casas-Solis, J.; Bravo-Cuellar, A.; Zaitseva, G. Oxidative stress in macrophages from spleen of Nile tilapia (Oreochromis niloticus) exposed to sublethal concentration of endosulfan. Fish Shellfish Immunol. 2009, 27, 105-111. [CrossRef] 
28. Hussein, M.M.A.; Elsadaawy, H.A.; El-Murr, A.; Ahmed, M.M.; Bedawy, A.M.; Tukur, H.A.; Swelum, A.A.A.; Saadeldin, I.M. Endosulfan toxicity in Nile tilapia (Oreochromis niloticus) and the use of lycopene as an ameliorative agent. Comp. Bioche. Phys. C 2019, 224, 108573. [CrossRef]

29. Suresh, N. Effect of cadmium chloride on liver, spleen and kidney melano macrophage centres in Tilapia mossambica. J. Environ. Biol. 2009, 30, 505-508. [CrossRef]

30. Zarejabad, A.M.; Jalali, M.A.; Sudagar, M.; Pouralimotlagh, S. Hematology of great sturgeon (Huso huso Linnaeus, 1758) juvenile exposed to brackish water environment. Fish. Physiol. Biochem. 2010, 36, 655-659. [CrossRef]

31. Xu, L.W.; Feng, J.; Guo, Z.X.; Lin, H.Z.; Guo, G.X. Effect of salinity on hematology and gill $\mathrm{Na}^{+}-\mathrm{K}^{+}$ATPase activity of juvenile cobia, Rachycentron canadum Linnaeus. Mar. Environ. Sci. 2008, 27, 602-606. [CrossRef]

32. Kavya, K.S.; Jadesh, M.; Kulkarni, R.S. Hematology and serum biochemical changes in response to change in saline concentration in fresh water fish Notopterus notopterus. World Sci. News 2016, 32, 49-60.

33. Jarvis, P.L.; Ballantyne, J.S. Metabolic responses to salinity acclimation in juvenile shortnose sturgeon Acipenser brevirostrum. Aquaculture 2003, 219, 891-909. [CrossRef]

34. Zhang, M.L.; Sun, Y.H.; Liu, Y.K.; Qiao, F.; Chen, L.Q.; Liu, W.T.; Du, Z.Y.; Li, E.C. Response of gut microbiota to salinity change in two euryhaline aquatic animals with reverse salinity preference. Aquaculture 2016, 454, 72-80. [CrossRef]

35. Readman, G.D.; Owen, S.F.; Knowles, T.G.; Murrell, J.C. Species specific anaesthetics for fish anaesthesia and euthanasia. Sci. Rep. 2017, 7, 1-7. [CrossRef] [PubMed]

36. Laria, C.; Saoca, C.; Guerrera, M.C.; Ciulli, S.; Brundo, M.V.; Piccione, G.; Lanteri, G. Occurrence of diseases in fish used for experimental research. Lab. Anim. 2019, 53, 619-629. [CrossRef]

37. Meena, D.K.; Das, P.; Kumar, S.; Mandal, S.C.; Prusty, A.K.; Singh, S.K.; Akhtar, M.S.; Behera, B.K.; Kumar, K.; Pal, A.K.; et al. Beta-glucan: An ideal immunostimulant in aquaculture (a review). Fish. Physiol. Biochem. 2013, 39, 431-457. [CrossRef]

38. Lin, S.M.; Pan, Y.; Luo, L.; Luo, L. Effects of dietary $\beta-1,3$-glucan, chitosan or raffinose on the growth, innate immunity and resistance of koi (Cyprinus carpio koi). Fish Shellfish Immunol. 2011, 31, 788-794. [CrossRef]

39. Ji, L.Q.; Sun, G.X.; Li, J.; Wang, Y.; Du, Y.S.; Li, X.; Liu, Y. Effect of dietary $\beta$-glucan on growth, survival and regulation of immune processes in rainbow trout (Oncorhynchus mykiss) infected by, Aeromonas salmonicida. Fish Shellfish Immunol. 2017, 64, 56-67. [CrossRef]

40. El-Murr Abd elhakeem, I.; Hakim, Y.A.E.; Neamat-Allah, A.N.F.; Baeshen, M.; Ali, H.A. Immune-protective, antioxidant and relative genes expression impacts of $\beta$-glucan against fipronil toxicity in Nile tilapia, Oreochromis niloticus. Fish Shellfish Immunol. 2019, 94, 427-433. [CrossRef]

41. Zhao, Y.C.; Ma, H.M.; Zhang, W.B.; Ai, Q.H.; Mai, K.S.; Xu, W.; Wang, X.J.; Liu, Z.G. Effects of dietary $\beta$-glucan on the growth, immune responses and resistance of sea cucumber, Apostichopus japonicus against Vibrio splendidus infection. Aquaculture 2011, 315, 269-274. [CrossRef]

42. Divya, M.; Gopi, N.; Iswarya, A.; Govindarajan, M.; Alharbi, N.S.; Kadaikunnan, S.; Khaled, J.M.; Almanaa, T.N.; Vaseeharan, B. $\beta$-glucan extracted from eukaryotic single-celled microorganism Saccharomyces cerecisiae: Dietary supplementation and enhanced ammonia stress tolerance on Oreochromis mossambicus. Microb. Pathog. 2020, 139, 103917. [CrossRef] [PubMed]

43. Bagni, M.; Romano, N.; Finoia, M.G.; Abelli, L.; Scapigliati, G.; Tiscar, P.G.; Sarti, M.; Marino, G. Short- and long-term effects of a dietary yeast beta-glucan (Macrogard) and alginic acid (Ergosan) preparation on immune response in sea bass (Dicentrarchus labrax). Fish Shellfish Immunol. 2005, 18, 311-325. [CrossRef] [PubMed]

44. Lu, D.L.; Limbu, S.M.; Lv, H.B.; Ma, Q.; Chen, L.Q.; Zhang, M.L.; Du, Z.Y. The comparisons in protective mechanisms and efficiencies among dietary $\alpha$-lipoic acid, $\beta$-glucan and l-carnitine on Nile tilapia infected by Aeromonas hydrophila. Fish Shellfish Immunol. 2018, 86, 785-793. [CrossRef] [PubMed]

45. Cao, H.Z.; Yu, R.H.; Zhang, Y.Y.; Hu, B.Q.; Jian, S.Q.; Wen, C.G.; Kajbaf, K.; Kumar, V.; Yang, G. Effects of dietary supplementation with $\beta$-glucan and Bacillus subtilis on growth, fillet quality, immune capacity, and antioxidant status of Pengze crucian carp (Carassius auratus var. Pengze). Aquaculture 2019, 508, 106-112. [CrossRef]

46. Abdelhamid, F.M.; Elshopakey, G.E.; Aziza, A.E. Ameliorative effects of dietary Chlorella vulgaris and $\beta$-glucan against diazinon-induced toxicity in Nile tilapia (Oreochromis niloticus). Fish Shellfish Immunol. 2020, 96, 213-222. [CrossRef]

47. Uribe, C.; Folch, H.; Enriquez, R.; Moran, G. Innate and adaptive immunity in teleost fish: A review. Vet. Med. 2011, 56, 486-503. [CrossRef] 
48. De Oliveira, C.A.F.; Vetvicka, V.; Zanuzzo, F.S. $\beta$-Glucan successfully stimulated the immune system in different jawed vertebrate species. Comp. Immunol. Diagn. Microbiol. Infect. Dis. 2019, 62, 1-6. [CrossRef]

49. Huu, H.D.; Sang, H.M.; Thanh, T.N.T. Dietary $\beta$-glucan improved growth performance, Vibrio counts, haematological parameters and stress resistance of pompano fish, Trachinotus ovatus Linnaeus, 1758. Fish Shellfish Immunol. 2016, 54, 402-410. [CrossRef]

50. Sahoo, P.K.; Mukherjee, S.C. Effect of dietary beta-1,3 glucan on immune responses and disease resistance of healthy and aflatoxin B1-induced immunocompromised rohu (Labeo rohita Hamilton). Fish Shellfish Immunol. 2001, 11, 683-695. [CrossRef]

51. Flavell, R.A. The relationship of inflammation and initiation of autoimmune disease: Role of TNF super family members. Curr. Top. Microbiol. Immun. 2002, 266, 1-9. [CrossRef]

52. Pallai, A.; Kiss, B.; Vereb, G.; Armaka, M.; Kollias, G.; Szekanecz, Z.; Szondy, Z. Transmembrane TNF-Reverse signaling inhibits lipopolysaccharide-induced proinflammatory cytokine formation in macrophages by inducing TGF-: Therapeutic implications. J. Immunol. 2016, 196, 1146-1157. [CrossRef] [PubMed]

53. Netea, M.G.; Simon, A.; De Veerdonk, F.V.; Kullberg, B.J.; Van der Meer, J.W.; Joosten, L.A. IL-1beta processing in host defense: Beyond the inflammasomes. PLoS Pathol. 2010, 6, e1000661. [CrossRef] [PubMed]

54. Goetz, F.W.; Planas, J.V.; MacKenzie, S. Tumor necrosis factors. Dev. Compar. Immunol. 2004, 28, 487-497. [CrossRef] [PubMed]

55. Falco, A.; Frost, P.; Miest, J.; Pionnier, N.; Irnazarow, I.; Hoole, D. Reduced inflammatory response to Aeromonas salmonicida infection in common carp (Cyprinus carpio L.) fed with $\beta$-glucan supplements. Fish Shellfish Immunol. 2012, 32, 1051-1057. [CrossRef] [PubMed]

56. Sparkes, A.; De Baetselier, P.; Roelants, K.; Trez, C.D.; Magez, S.; Ginderachter, J.A.V.; Raes, G.; Bucala, R.; Stijlemans, B. The non-mammalian MIF superfamily. Immunobiology 2016, 222, 473-482. [CrossRef]

57. Douxfils, J.; Fierro-Castro, C.; Mandiki, S.N.M.; Emile, W.; Tort, L.; Kestemont, P. Dietary $\beta$-glucans differentially modulate immune and stress-related gene expression in lymphoid organs from healthy and, Aeromonas hydrophila-infected rainbow trout (Oncorhynchus mykiss). Fish Shellfish Immunol. 2017, 63, 285-296. [CrossRef]

58. Carlos, C.V.; Rodriguez, M.E.M.; Arizaga, G.G.C.; Jara, J.S.; Angulo, C.; Becerril, M.R. Immobilizing yeast $\beta$-glucan on zinc-layered hydroxide nanoparticle improves innate immune response in fish leukocytes. Fish Shellfish Immunol. 2018, 82, 504-513. [CrossRef]

59. Metzler-Zebeli, B.U.; Ganzle, M.G.; Mosenthin, R.; Zijlstra, R.T. Oat $\beta$-glucan and dietary calcium and phosphorus differentially modify intestinal expression of proinflammatory cytokines and monocarboxylate transporter 1 and cecal morphology in weaned pigs. J. Nutr. 2012, 142, 668-674. [CrossRef]

60. McLoughlin, R.F.; Berthon, B.S.; Jensen, M.E.; Baines, K.J.; Wood, L.G. Short-chain fatty acids, prebiotics, synbiotics, and systemic inflammation: A systematic review and meta-analysis. Am. J. Clin. Nutr. 2017, 106, 930-945. [CrossRef]

61. Carballo, C.; Pinto, P.I.S.; Mateus, A.P.; Berbel, C.; Guerreiro, C.C.; Martinez-Blanch, J.F.; Codoner, F.M.; Mantecon, L.; Power, D.M.; Manchado, M. Yeast $\beta$-glucan and microalgal extracts modulate the immune response and gut microbiome in Senegalese sole (Solea senegalensis). Fish Shellfish Immunol. 2019, 92, 31-39. [CrossRef] [PubMed]

62. Yang, G.; Xu, Z.J.; Tian, X.L.; Dong, S.L.; Peng, M. Intestinal microbiota and immune related genes in sea cucumber (Apostichopus japonicus) response to dietary $\beta$-glucan supplementation. Biochem. Bioph. Res. Co. 2015, 458, 98-103. [CrossRef] [PubMed]

63. Siriyappagouder, P.; Galindo-Villegas, J.; Lokesh, J.; Mulero, V.; Fernandes, J.M.O.; Kiron, V. Exposure to yeast shapes the intestinal bacterial community assembly in zebrafish larvae. Front. Microbiol. 2018, 9, 1868. [CrossRef] [PubMed]

64. Zhou, L.; Chen, C.Z.; Xie, J.; Xu, C.; Zhao, Q.; Jian, G.Q.I.N.; Chen, L.Q.; Li, E.C. Intestinal bacterial signatures of the "cotton shrimp-like" disease explain the change of growth performance and immune responses in Pacific white shrimp (Litopenaeus vannamei). Fish Shellfish Immunol. 2019, 92, 629-636. [CrossRef] [PubMed]

65. Gatesoupe, F.J. Updating the importance of lactic acid bacteria in fish farming: Natural occurrence and pro-biotic treatments. J. Mol. Microb. Biotech. 2008, 14, 107-114. [CrossRef] [PubMed]

66. Jaskari, J.; Kontula, P.; Siitonen, A.; Somer, H.J.; Sandholm, T.M.; Poutanen, K. Oat $\beta$-glucan and xylan hydrolysates as selective substrates for Bifidobacterium and Lactobacillus strains. App. Microbiol. Biotechnol. 1998, 49, 175-181. [CrossRef] [PubMed] 
67. Foysal, M.J.; Alam, M.; Kawser, A.Q.M.R.; Hasan, F.; Rahman, M.M.; Tay, C.Y.; Prodhan, M.S.H.; Gupta, S.K. Meta-omics technologies reveals beneficiary effects of Lactobacillus plantarum as dietary supplements on gut microbiota, immune response and disease resistance of Nile tilapia (Oreochromis niloticus). Aquaculture 2020, 520, 734974. [CrossRef]

68. Johnson, D.B. Biodiversity and ecology of acidophilic microorganisms. FEMS Microbiol. Ecol. 1998, 27, 307-317. [CrossRef]

69. Yang, X.Z.; Xu, M.J.; Huang, G.Y.; Zhang, C.; Pang, Y.Y.; Cheng, Y.X. Effect of dietary L-tryptophan on the survival, immune response and gut microbiota of the Chinese mitten crab, Eriocheir sinensis. Fish Shellfish Immunol. 2019, 84, 1007-1017. [CrossRef]

70. Yu, L.; Rahman, S.U.; Huang, Y.Y.; Zhang, Y.F.; Ming, P.F.; Zhu, L.; Chu, X.Y.; Li, J.C.; Feng, S.B.; Wang, X.H.; et al. Green tea polyphenols decrease weight gain, ameliorate alteration of gut microbiota, and mitigate intestinal inflammation in canines with high-fat-diet-induced obesity. J. Nutr. Biochem. 2020, 78, 108324. [CrossRef]

71. Tzelepis, G.; Karlsson, M. Killer toxin-like chitinases in filamentous fungi: Structure, regulation and potential roles in fungal biology. Fungal Biol. Rev. 2018, 33, 123-132. [CrossRef]

72. Oh, M.; Zhang, T.; Seljelid, R.; Li, X. Treptomyces cerevisiae 1,3/1,6 beta-glucan prevents airway hyperreactivity and pulmonary inflammation in a murine asthma model. J. Allergy Clin. Immunol. 2007, 119, S6. [CrossRef]

73. Zarantoniello, M.; Zimbelli, A.; Randazzo, B.; Compagni, M.D.; Truzzi, C.; Antonucci, M.; Riolo, P.; Loreto, N.; Osimani, A.; Milanović, V.; et al. Black Soldier Fly (Hermetia illucens) reared on roasted coffee by-product and Schizochytrium sp. as a sustainable terrestrial ingredient for aquafeeds production. Aquaculture 2019, 518, 734659. [CrossRef]

74. Zheng, Y.; Wu, W.; Hu, G.D.; Qin, L.P.; Meng, S.L.; Song, C.; Fan, L.M.; Zhao, Z.X.; Bing, X.W.; Chen, J.Z. Gut microbiota analysis of juvenile genetically improved farmed tilapia (Oreochromis niloticus) by dietary supplementation of different resveratrol concentrations. Fish Shellfish Immunol. 2018, 77, $200-207$. [CrossRef] [PubMed]

75. Almeidaa, A.R.; Alvesb, M.; Dominguesa, I.; Henriques, I. The impact of antibiotic exposure in water and zebrafish gut microbiomes: A $16 \mathrm{~S}$ rRNA gene-based metagenomic analysis. Ecotox. Environ. Safe. 2019, 186, 109771. [CrossRef] [PubMed]

76. Ye, J.Z.; Lv, L.X.; Wu, W.R.; Li, Y.T.; Shi, D.; Fang, D.Q.; Guo, F.F.; Jiang, H.Y.; Yan, R.; Ye, W.C.; et al. Butyrate protects mice against methionine-choline-deficient diet-induced nonalcoholic steatohepatitis by improving gut barrier function, attenuating inflammation and reducing endotoxin levels. Front. Microbiol. 2018, 9, 1967. [CrossRef]

77. Geraylou, Z.; Souffreau, C.; Rurangwa, E.; Maes, G.E.; Spanier, K.I.; Courtin, C.M.; Delcour, J.A.; Buyse, J.; Ollevier, F. Prebiotic effects of arabinoxylan oligosaccharides on juvenile Siberian sturgeon (Acipenser baerii) with emphasis on the modulation of the gut microbiota using 454 pyrosequencing. FEMS Microbiol. Ecol. 2013, 86, 357-371. [CrossRef]

78. Coyte, K.Z.; Schluter, J.; Foster, K.R. The ecology of the microbiome: Networks, competition, and stability. Science 2015, 350, 663. [CrossRef]

79. Zhou, J.; Deng, Y.; Luo, F.; He, Z.; Yang, Y. Phylogenetic molecular ecological network of soil microbial communities in response to elevated $\mathrm{CO}_{2}$. MBio 2011, 2, e00122-11. [CrossRef]

80. Deng, Y.; Jiang, Y.; Yang, Y.; He, Z.; Luo, F.; Zhou, J. Molecular ecological network analyses. BMC Bioinform. 2012, 13, 113. [CrossRef]

81. Pande, S.; Kaftan, F.; Lang, S.; Svatoš, A.; Germerodt, S.; Kost, C. Privatization of cooperative benefits stabilizes mutualistic cross-feeding interactions in spatially structured environments. ISME J. 2016, 10, 1413. [CrossRef] [PubMed]

Publisher's Note: MDPI stays neutral with regard to jurisdictional claims in published maps and institutional affiliations. 